\title{
Yessotoxins profile in strains of Protoceratium reticulatum from Spain and USA
}

\author{
Beatriz Paza ${ }^{\mathrm{a},{ }^{*}}$, Pilar Riobó ${ }^{\mathrm{a}}$, Isabel Ramilo ${ }^{\mathrm{b}}$, José M. Franco ${ }^{\mathrm{a}}$ \\ ${ }^{a}$ Fitoplancton Tóxico, Instituto Investigaciones Marinas (CSIC), Eduardo Cabello 6, \\ 36208 Vigo, Spain \\ ${ }^{b}$ Fitoplancton Tóxico, Instituto Español de Oceanografía, Centro Oceanografico de Vigo \\ (IEO), Cabo Estay, Apdo 1552, 36200 Vigo, España, Spain
}

\begin{abstract}
Seven strains of Protoceratium reticulatum isolated from Spain and the USA were cultured in the laboratory. Yessotoxins (YTXs) quantification and toxin profile determination were performed by LC-FLD and LC-MS/MS. The four Spanish strains were found to produce YTX and known YTX analogs, however, YTX was not detected in any of the three USA strains. Among the strains that produced YTXs, toxin production ranged between 2.9 and $28.6 \mathrm{pg} / \mathrm{cell}$. The YTX profile was substantially different between strains, in three out of the four Spanish strains YTX was the main toxin and in the fourth homoYTX was the prominent toxin. This work demonstrates that YTX is not always the main toxin in P. reticulatum and a high variability in YTX amounts and profile found in other locations is confirmed.
\end{abstract}

Keywords: Protoceratium reticulatum; Strains; YTXs; HomoYTXs; LC-FLD; LCMS/MS; Toxin profile

\section{Introduction}

Yessotoxins (YTXs), a group of disulphated polyether toxins, are mainly produced by the dinoflagellate Protoceratium reticulatum (Clapare de et Lachmann) Bütschli ( = Gonyaulax grindleyi Reinecke) and have been reported in strains from New Zealand (Satake et al., 1997), Japan (Satake et al., 1999), Norway (Ramstad et al., 2001; Samdal et al., 2004), Italy (Ciminiello et al., 2003b), UK, Canada (Stobo et al., 2003) and Spain (Paz et al., 2004). YTXs are accumulated in shellfish and are toxic to mice when injected intraperioneally (Aune et al., 2002; Tubaro et al., 2003), causing false positives in the mouse bioassay for diarrhetic shellfish poisoning (DSP). YTXs have been found 
to be nondiarrhoeic toxins to humans (Tubaro et al., 1998; De la Rosa et al., 2001; Alfonso et al., 2003) but have been found to be potent cytotoxins (Bianchi et al., 2004; Konishi et al., 2004; Pé rez- Gó mez et al., 2006). The European Union established a maximum level permitted in shellfish of $1 \mathrm{mg} / \mathrm{Kg}$ (CEE, 2002). YTXs have been detected in shellfish in Japan (Murata et al., 1987), Norway (Aesen et al., 2005), Chile, New Zealand (Yasumoto and Takizawa, 1997), Italy (Yasumoto and Takizawa, 1997; Ciminiello et al., 2003a) and Spain (Aré valo et al., 2004; Mallat et al., 2006).

P. reticulatum produces a rich array of YTX analogs, which have recently been discovered and isolated. The existence of about 100 analogs in P. reticulatum have been reported, although only the structure of about 22 of them have been identified (Miles et al., 2006a). The YTX production and toxin profile in different P. reticulatum strains have been found to be dependent on the origin of the strain (Ciminiello et al., 2003b; Eiki et al., 2005; Samdal et al., 2006). For instance trinorYTX, the first analog discovered in algae (Satake et al., 1999), was detected in Japanese (Satake et al., 1999) and Norwegian (Samdal et al., 2006) strains, but not in New Zealand strains (Miles et al., 2005a). Other YTX analogs, 1a-homoYTX, noroxoYTX, 45- hydroxyYTX and carboxyYTX, have been found in one Italian strain (Ciminiello et al., 2003b). But there is some disagreement about the occurrence of 45-hydroxyYTX and carboxyYTX in algae, because evidence suggests that they are produced mainly by the metabolism in shellfish (Aesen et al., 2005). In a New Zealand strain, which was studied in depth, a complex YTX profile has been reported with a wide range of analogs not detected until now in any other strains such as 40-epi-YTX and YTX-enone isomers of noroxoYTX (Miles et al., 2004), 41a-homoYTXs, 9-methyl-4la-homoYTXs, nor-ring-A-YTXs (Miles et al., 2005a), 44,55-dihydroxyYTXs derived from 41a-homoYTX and 9-methyl41a-homoYTX (Finch et al., 2005), hidroxy-amideYTXs derived from the 41ahomoYTXs and 9-methyl-41a-homo- YTX (Miles et al., 2005b), 45-OHdinorYTX, oxotrinorYTXs (Miles et al., 2006a). The 32-Omono- and di-glycosylYTXs were detected in strains from Japan, Spain and New Zealand (Cooney et al., 2003; Souto et al., 2005; Miles et al., 2006b) and the 32-O-mono, -di- and -tri-arabinosides of 1ahomo- YTX, until now, were only detected in two strains isolated in Japan (Konishi et al., 2004). In other Japanese strains the trinorhomoYTX was also detected (Satake et al., 2006). Nevertheless, in spite of the high variability in the reported YTX profile, it seems that the major toxin in P. reticulatum is usually YTX, and only homoYTX, together 
with 32-O-mono, -di- and -tri-arabinosides of 1a-homo- YTX, which was found to be the main toxin in two Japanese strains (Konishi et al., 2004). Moreover, the amount of YTXs produced by each strain was different, ranging from 0 to $34 \mathrm{pg} / \mathrm{cell}$. This variability in production could be due to the strain, but also due to the different culture conditions, method of extraction or method of analysis used (Stobo et al., 2003; Eiki et al., 2005; Samdal et al., 2006). It is also assumed that YTX amounts and profile in shellfish are dependent on the profile of each dinoflagellate strain.

Therefore investigation of different strains, regarding the YTXs profile, the amounts of toxin produced and its possible release into the medium, is essential in order to determine the potential toxicity of each P. reticulatum strain. Taking this into account, the present study has focused on the determination of YTX production and YTX profile in several Spanish and USA strains of P. reticulatum.

2. Material and methods

\subsection{Cultures}

The seven strains of P. reticulatum, used in this study, were obtained from the collection of phytoplankton cultures at the Centro Oceanografico in Vigo. Strains VGO757, VGO758 and VGO764 were isolated from cysts in the Lagoon El Alfacs (Delta del Ebro, Spain). The other four strains were isolated from cells, GG1AM in La Atunara, (Cadiz, Spain), CCMP404 in Salton Sea (California, USA), CCMP1720 and CCMP1721 in Biscaney Bay (Florida, USA) (Table 1).

The species of the USA strains were identified in the CCMP and the species of the Spanish strains were identified in the CCVIEO: GG1AM strain by Santiago Fraga and VGO 757, 758 and 764 by Isabel Bravo. In order to calculate the biovolume, cells were assumed to be spheres and their diameters were measured with the aid of a micrometer eyepiece using the average value between length and width, $n=30$. ANOVA $(p<0.05)$ was used to compare the cell volume of the different strains.

All of the cultures were grown in $3 \mathrm{~L}$ Erlenmeyer flasks containing $2 \mathrm{~L}$ of L1 medium without silicates (Guillard and Hargraves, 1993). Cultures were inoculated with 35- 
$65 \mathrm{~mL}(500$ cells $/ \mathrm{mL})$ in the exponentially growing phase of each P. reticulatum strain, maintained at $19 \pm 1{ }^{\circ} \mathrm{C}$, at a salinity of 30 and under an irradiance of $100-125 \mu \mathrm{mol}$ photons $/ \mathrm{m}^{2}$. s on a 12:12 h light:darkness regime. Cultures were gently shaken once a day. To determine cell yield, $5 \mathrm{~mL}$ aliquots of samples were collected when cultures reached the stationary phase at 31-33 days (Table 1). Cells were fixed with Lugol's solution and were counted by optical microscopy in a Sedgewick- Rafter chamber.

\subsection{YTXs extraction}

YTXs were extracted from cells and culture medium, separately. For this purpose, $50 \mathrm{~mL}$ aliquots of each culture were harvested in the stationary phase, which was reached at 31-33 days depending on the strain (Table 1) and were filtered through 1.4 $\mu \mathrm{mGF} / \mathrm{C}$ glass fiber filters (25mm diameter) (Whatman, Maidstone, England). The cells in the filter were extracted twice with $\mathrm{MeOH}$. The $\mathrm{MeOH}$ cell extract and the filtered culture medium were respectively loaded onto two different Sep-Pak C18 light cartridges (Waters USA) for the purification of YTXs in solid phase (SPE). Cartridges were washed with $4 \mathrm{~mL}$ of $20 \% \mathrm{MeOH}$ and YTXs were eluted using $4 \mathrm{~mL}$ of $70 \%$ $\mathrm{MeOH}$. This fraction was dried under a $\mathrm{N}_{2}$ stream and resuspended in $0.5 \mathrm{~mL}$ of $\mathrm{MeOH}$ for LC-MS analysis or derivatized with DMEQ-TAD, re-suspended in $\mathrm{MeOH}$ and finally quantified by LC-FLD (Paz et al., 2006).

In previous studies it has been found that toxin is released into the medium. The proportion of toxin between medium and cells varies depending on the culture phase (Paz et al., 2004, 2006). Therefore all the toxin produced by cells in terms of pg/cell, was determined as the sum of YTXs in both culture medium and cells

\subsection{Toxin analysis by LC- FLD}

YTX determination and quantification were performed by LC-FLD. Analysis was carried out by a system equipped with a Hitachi L-6200 A pump, a Jasco FP-920 fluorescence detector, a Hitachi AS-4000 autosampler and a Lichrospher 100 RP18 5 $\mu \mathrm{m}(4.6 \times 125 \mathrm{~mm})$ cartridge column. A mobile phase of $100 \mathrm{mM}$ ammonium acetate, $\mathrm{pH} 5.8: \mathrm{MeOH}(3: 7)$ at a flow rate of $0.75 \mathrm{~mL} / \mathrm{min}$ and $35^{\circ} \mathrm{C}$ column temperature, was 
used. The excitation and emission wavelengths were 370 and $440 \mathrm{~nm}$, respectively (Yasumoto and Takizawa, 1997; Paz et al., 2004).

\subsection{Toxin analysis by LC-MS}

For YTXs identification a LC-MS system was used. The separation column was an Xterra MS C18 $5 \mu \mathrm{m}\left(2.1 \_150 \mathrm{~mm}\right)$ cartridge at $35^{\circ} \mathrm{C}$. As mobile phase $2 \mathrm{mM}$ ammonium acetate (pH 5.8) (A) and $\mathrm{MeOH}(\mathrm{B})$, in a gradient elution (40-30\% A in 5 $\min , 30-20 \% \mathrm{~A}$ in $5 \mathrm{~min}$, followed by $5 \mathrm{~min}$ with $20 \% \mathrm{~A}$, then $20-0 \% \mathrm{~A}$ in $5 \mathrm{~min}$ and $0 \%$ A for $2 \mathrm{~min}$ ), were used. As flow rate and injection volume, $0.20 \mathrm{~mL} / \mathrm{min}$ and $10 \mu \mathrm{L}$ were used, respectively. Mass spectral measurements were performed using an ion trap mass spectrometer, Thermo Finnigan LCQ-Advantage, equipped with a microelectrospray ionization ( $\mu \mathrm{ESI})$, in negative ion mode. ESI was performed with a $4.5 \mathrm{kV}$ spray voltage and $200{ }^{\circ} \mathrm{C}$ capillary temperature, flow $15 \mathrm{~mL} / \mathrm{min}$ for sheath gas and $5 \mathrm{~mL} / \mathrm{min}$ for auxiliary gas. Full scan data were acquired from $\mathrm{m} / \mathrm{z} 500$ to 2000 . MS spectrum shifted prominent ions at $\mathrm{m} / \mathrm{z}[\mathrm{M}-\mathrm{H}]^{-},[\mathrm{M}-2 \mathrm{H}+\mathrm{Na}]^{-}$and $[\mathrm{M}-2 \mathrm{H}]^{-2}$, in different proportions depending on the YTX analog. Therefore for MS quantification the three prominent ions for each analog were selected. The contribution percentages of each analog to the total YTXs production for medium and cells were calculated, separately. Subsequent LC-MS ${ }^{3}$ for YTXs were performed by applying a supplementary voltage (Collision Energy, CE) of $35 \%$ and $40 \%$ on the $[\mathrm{M}-\mathrm{H}]^{-}$ion.

For YTXs identification by LC-FLD and LC-MS a YTX standard purchased from the Institute of Environmental Science and Research Limited (New Zealand), a 45-OHYTX and carboxyYTX standards provided by Professor T. Yasumoto and a G-YTXA extract purified from cells of P. reticulatum (Souto et al., 2005) were used. The same YTXs standards were used for homoYTXs identification because homoYTXs eluted in the same retention times as YTX homologues and the fragmentation pattern is superimposable on that of YTXs, but shifted in 14 mass units (Ciminiello et al., 2003b). However quantification was performed using just the YTX standard, due to the lack of appropriate standards for all the YTX and homo- YTX analogs detected. The assumption was made that all the analogs would give the same molar response as YTX. 
3. Results and discussion

\subsection{Cultures of $P$. reticulatum}

Under the culture conditions used in the current study, the seven strains of P. reticulatum achieved the stationary phase in about 31-33 days depending on the strain. The cell yield ranged among strains between 4396 and 24180 cell $/ \mathrm{mL}$. The lowest cell density was achieved by CCMP404 and the highest by VGO764 (Table 1).

The cell biovolume ranged from 3.7 to $12.4 \times 10^{3} \mathrm{~mm}^{3}$. The strain with smallest volume was VGO764 and the highest was CCMP1720 (Fig. 1). No significant differences $(\mathrm{p}<0.05)$ in cell biovolume were found among the strains CCMP1720, CCMP1721 and CCMP404, the same occurred among the strains GG1AM, VGO757 and VGO758. However, significant differences $(\mathrm{p}<0.05)$ in biovolume were found between the strains CCMP1720, CCMP1721 and CCMP404 with regard to the strains GG1AM, VGO757, VGO758 and VGO764 ( $<<0.05)$. Furthermore there were significant differences $(\mathrm{p}<0.05)$ between the strains GG1AM, VGO757 and VGO758 with regard to VGO764. (Fig. 1).

\subsection{LC- FLD determination and quantification of YTX}

Chromatographic analysis of the SPE $70 \% \mathrm{MeOH}$ fraction of both, medium and cells showed the characteristic double peak for derivatized YTX only in the four Spanish strains. Comparison with the retention time of the YTX standard (Fig. 2), demonstrated YTX production by the four Spanish strains: GG1AM, VGO758, VGO757 and VGO764 (Fig. 2). The three USA strains: CCMP404, CCMP1720 and CCMP1721, were confirmed as not producing YTXs (Fig. 2). Owing to the fact some reported YTX analogs are more polar than others (Miles et al., 2005a), the $20 \% \mathrm{MeOH}$ fraction of the SPE purification was analysed, but derivatized YTXs were not detected in any of the strains

Total toxin production differed from strain to strain, between 2.9 and $28.6 \mathrm{pg} / \mathrm{cell}$. The least productive one was GG1AM and the most was VGO758, whereas YTX was not detected in strains CCMP404, CCMP1720 and CCMP1721 (Table 1). Under the current 
culture conditions YTX was found both, inside cells and in the culture medium, at the end of the culture. In all the strains most of the toxin remains inside the cells, in differring percentages, depending on the strain (Table 1). In VGO758 and GG1AM strains the quantity of toxin released into the culture medium represents $35 \%$ and $38 \%$ of total toxin, respectively (Table 1), this being a considerable amount. These percentages are not a permanent characteristic of the strains, because cellular content of toxin is subject to culture conditions and varies substantially depending on the culture phase (Paz et al., 2004, 2006).

The Spanish strains contained similar levels of YTX to those found in isolates from Japan, Italy or New Zealand, determined by LC-FLD or LC-MS, in which the YTX content ranged from 0.3 to 15.7 pg/cell (Satake et al., 1999; Boni et al., 2000; Stobo et al., 2003; Ciminiello et al., 2003b; Eiki et al., 2005; Mitrovic et al., 2005; Rhodes et al., 2006) (Table 2). Nevertheless, amounts of YTX detected were lower to that obtained in some New Zealand and Norwegian strains, 30-34 pg/cell, determined by ELISA (Samdal et al., 2004) (Table 2). It has been reported that differences in toxin concentration, were due to different analytical methods employed, because some YTX analogs were quantified by ELISA but not by LC-MS or LC-FLD (Samdal et al., 2005). The antibodies used in the ELISA analysis have a broad cross-reactivity with most of the YTX analogs, therefore ELISA detects all the YTX analogs jointly. Therefore samples with a mixture of analogs will give a higher result when analysed by ELISA than with chemical methods (LC-MS or LC-FLD) in which some of the YTX analogs may not be quantified, because they are determined separately. Taking this into account, it is likely that the productivity of those strains analysed by different analytical methods were in similar ranges. Consequently, to compare results it is essential that they be obtained with the same technique. The absence of YTX in some P. reticulatum strains has also been reported in New Zealand in the strain CAWD127 (Rhodes et al., 2006) and in Harina Nada, Japan (Satake et al., 1999) (Table 2).

Despite the LC-FLD method being effective for quantification and detection of YTX and some YTX analogs, it is not able to detect analogs without a conjugated diene in the side chain, as in carboxyYTX, carboxyhomoYTX, adriatoxin or diOHYTXs. Another disadvantage is that homo- YTXs peaks overlap with YTXs peaks and are 
indistinguishable. To elucidate the presence of YTXs analogs in the samples it was necessary to apply the LC-MS/MS analysis.

\subsection{LC-MS/MS identification of YTXs}

Identification of YTX analogs were performed by LC-MS and MS3. The two fractions harvested in the SPE cleanup from both, culture medium and cells were analysed. YTXs were only detected in the $70 \% \mathrm{MeOH}$ fraction. The Spanish strains VGO757, VGO758 and GG1AM showed a similar toxin profile, in which YTX was the main toxin, together with small quantity of YTX analogs (Fig. 3). In contrast, in the VGO764 strain the homoYTX was the main toxin and the minor components determined were analogs of the homoYTX (Fig. 4). As was previously determined by LC-FLD, YTX or any of the analogs were not found in the USA strains. Retention time and spectrum of injected standards used for LC-MS assignment are shown in Fig. 5

\subsubsection{Profile of toxin in strains VGO757, VGO758 and GG1AM}

LC-MS and MS3 analysis of VGO757, VGO758 and GG1AM strains revealed the presence of YTX with $\mathrm{m} / \mathrm{z} 1141$ (11.18 min) as the main toxin, together with noroxoYTX-enone at m/z 1047 (8.12 min), 32-O-monoglycosylYTX at m/z 1273 (10.45 min), two unknown YTX analogs with $\mathrm{m} / \mathrm{z} 1173$ (8.08 $\mathrm{min}$ ) and with $\mathrm{m} / \mathrm{z} 1157$ (9.15 min), respectively. Also trace amounts of 44,55-diOH- 41a-homoYTX at $\mathrm{m} / \mathrm{z}$ 1189 ( $8.61 \mathrm{~min})$, 32-OdiglycosylYTX at $\mathrm{m} / \mathrm{z} 702$ (9.72 $\mathrm{min}$ ) and homo- YTX with $\mathrm{m} / \mathrm{z}$ 1155 (11.12 $\mathrm{min}$ ) (Tables 3 and 4) were detected. Without ruling out the possibility that these strains also contain other known and unknown YTX analogs. The assignment of these analogs is described below

Ion $\mathrm{m} / \mathrm{z} 1173[\mathrm{M}-\mathrm{H}]^{-}$(8.08 $\left.\mathrm{min}\right)$ : This ion was the first detected by LC-MS analyses (Fig. 3a). The extracted ion chromatogram also showed prominent ions at m/z 587 [M$2 \mathrm{H}]^{-2}$ and $\mathrm{m} / \mathrm{z} 1195[\mathrm{M}-2 \mathrm{H}+\mathrm{Na}]^{-}$. MS2 fragmentation of the m/z $1173[\mathrm{M}-\mathrm{H}]^{-}$ion gave an ion at m/z $1093\left[\mathrm{M}-\mathrm{SO}_{3} \mathrm{H}\right]^{-}$. Additional MS3 fragmentation originated ions at m/z 924 and 855 (Fig. 6a). This daughter ions scheme was consistent with the characteristic fragmentation of the YTX side chain (Fig. 7). The retention time was different to that of 
carboxyYTX (4.69 min) (Fig. 5a). The mass and fragmentation pattern indicates that this compound with $\mathrm{m} / \mathrm{z} 1173[\mathrm{M}-\mathrm{H}]^{-}$should be the carboxiYTX, but the different retention time to that of carboxyYTX standard suggests that there is an unknown toxin belonging to the YTX group. A similar YTX analog was previously detected in algal samples, but its structure remains unidentified (Miles et al., 2005a). More structural studies will be necessary in order to fully identify this YTX analog.

Ion $\mathrm{m} / \mathrm{z} 1047[\mathrm{M}-\mathrm{H}]^{-}(8.12 \mathrm{~min})$ : This was the second compound detected by LC-MS (Fig. 3b) and showed the same mass as that of the three ketoYTXs (= noroxoYTX) (Ciminiello et al., 2003b; Miles et al., 2004). A common fragment at m/z 967 [M$\left.\mathrm{SO}_{3} \mathrm{H}\right]^{-}$for ketoYTXs was obtained in the $\mathrm{MS}^{2}$ analyses of the $\mathrm{m} / \mathrm{z} 1047[\mathrm{M}-\mathrm{H}]^{-}$ion. The $\mathrm{MS}^{3}$ fragmentation of $967\left[\mathrm{M}-\mathrm{SO}_{3} \mathrm{H}\right]^{-}$ion was difficult and only a very weak ion at $\mathrm{m} / \mathrm{z} 883$ was obtained (Fig. 7b), even when applying a high CE of 50. This fragment indicates that the $\mathrm{m} / \mathrm{z} 1047$ ion was the 1,3-enone isomer of heptanor-41-oxoYTX (= noroxoYTX-enone) (Miles et al., 2004) and not any of the other ketoYTX analogs (heptanor-41-oxoYTX or 40-epi-heptanor- 41-oxoYTX) (Ciminiello et al., 2002a; Miles et al., 2004).

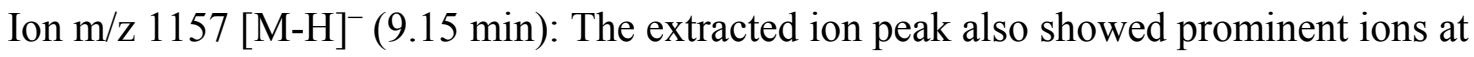
$\mathrm{m} / \mathrm{z} 578[\mathrm{M}-2 \mathrm{H}]^{-2}$ and $\mathrm{m} / \mathrm{z} 1179[\mathrm{M}-2 \mathrm{H}+\mathrm{Na}]^{-}$. The selectedion plot at $\mathrm{m} / \mathrm{z} 1157[\mathrm{M}-\mathrm{H}]^{-}$ gave a short, wide peak, as if there were several compounds with the same mass eluting at different times (Fig. 3c). An inspection of the MS/MS spectrum of the peak showed the typical fragmentation pattern of the 45-OHYTX: $\mathrm{MS}^{2}$ of m/z $1157[\mathrm{M}-\mathrm{H}]^{-}$ion

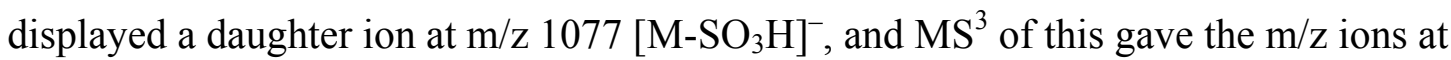
$\mathrm{m} / \mathrm{z}$ 924, 855 and 713 (Fig. 6c). Retention time did not show coincidence with 45OHYTX standard (8.32 min) (Fig. 6). This suggests the presence of a YTX analog different to 45-OHYTX. This is supported by the fact that most studies have indicated that 45-OHYTX is produced only by metabolism in shellfish. There was one study in which 45-OHYTX was found in algae (Ciminiello et al., 2003b), but chromatographic peaks for YTX analogs showed closed retention times, therefore 45-OHYTX standard and the $\mathrm{m} / \mathrm{z} 1157[\mathrm{M}-\mathrm{H}]^{-}$ion are practically indistinguishable. A series of four YTX analogs with m/z $1157[\mathrm{M}-\mathrm{H}]^{-}$, and different to 45- OHYTX, have also been found by 
Miles et al. (2004), however structures have not been determined yet. It is possible that our unknown YTXs at m/z $1157[\mathrm{M}-\mathrm{H}]^{-}$might be the same as that mentioned by Miles et al. (2004) because their fragmentation pattern and chromatographic behaviour were similar.

Ion $\mathrm{m} / \mathrm{z} 1273[\mathrm{M}-\mathrm{H}]^{-}(10.40 \mathrm{~min})$ : For this compound the prominent ion was di-charged at $\mathrm{m} / \mathrm{z} 636[\mathrm{M}-2 \mathrm{H}]^{2^{2}}$ (Fig. 3d) and the m/z $1295[\mathrm{M}-2 \mathrm{H}+\mathrm{Na}]^{-}$ion appeared at very low

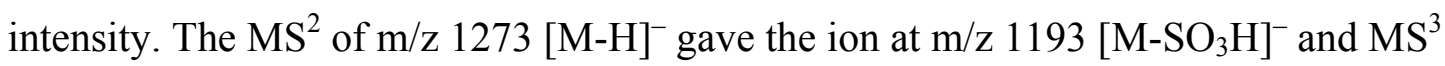
displayed daughter ions at m/z 1061, 1056 and 987 (Fig. 6d). The m/z 1061 ion was generated due to the loss of a pentose unit. The $\mathrm{m} / \mathrm{z} 1056$ and 987 ions maintain the pentose unit. The retention time and fragmentation pattern matches with the G-YTX A standard (=32-OmonoglycosylYTX) (Fig. 5c) (Souto et al., 2005; Paz et al., 2006).

Ion $\mathrm{m} / \mathrm{z} 1141[\mathrm{M}-\mathrm{H}]^{-}(11.18 \mathrm{~min})$ : This was the most relevant peak in these Spanish strains (Fig. 3e). MS ${ }^{3}$ analyses showed the $\mathrm{m} / \mathrm{z}$ 924, 855 and 713 ions, which is characteristic of YTX (Fig. 6e). Their assignment as YTX was confirmed using a YTX standard, which resulted in perfect coincidence in both retention time (Fig. 5d) and $\mathrm{MS}^{3}$ fragmentation.

Other minor compounds detected (data not shown): (i) The m/z $1189[\mathrm{M}-\mathrm{H}]^{-}$ion $(8.61$ min) was found in trace amounts in strains GG1AM and VGO 757. $\mathrm{MS}^{2}$ and $\mathrm{MS}^{3}$ fragmentation of m/z $1189[\mathrm{M}-\mathrm{H}]^{-}$gave two peaks at m/z 1109 and 925, respectively. This ion scheme indicated that it belonged to the YTXs series. It is possible that this compound will be the 44,55-diOH-41a-homoYTX, whose structure was recently elucidated in a New Zealand P. reticulatum strain (Finch et al., 2005). (ii) In strains GG1AM and VGO 758, the 32-OdiglycosylYTX (Miles et al., 2006b), was detected in trace amounts. This glycosyl derivative showed up as a prominent ion di-charged at $\mathrm{m} / \mathrm{z}$ $702[\mathrm{M}-2 \mathrm{H}]^{-2}$ together with $1427[\mathrm{M}-2 \mathrm{H}+\mathrm{Na}]^{-}$eluting at $9.72 \mathrm{~min}$, the nono-charged ion $\left(\mathrm{m} / \mathrm{z} 1403[\mathrm{M}-\mathrm{H}]^{-}\right)$was not detected. Fragmentation was not performed due to the small signal obtained. (iii) The m/z $1155[\mathrm{M}-\mathrm{H}]^{-}$ion (11.15 min), was also found in small quantities, eluting in the same retention time as YTX. $\mathrm{MS}^{3}$ fragmentation 
displayed the $\mathrm{m} / \mathrm{z} 938$ fragment characteristic of 1a-homoYTX. This was the only compound from the homoYTXs series found in these three strains.

\subsubsection{Profile of toxin in strain VGO764}

LC-MS and $\mathrm{MS}^{3}$ analysis of the VGO764 strain showed a very different YTX profile to that of the above mentioned strains. The main toxin was the 1a-homoYTX at m/z 1155 (11.12 $\mathrm{min})$, together with noroxohomoYTX-enone at $\mathrm{m} / \mathrm{z} 1061$ (8.03 $\mathrm{min})$, a possible 44,55-diOH-9-Me-1a-homo- YTX with m/z 1203 (8.55 min), 32-OdiglycosylhomoYTX at m/z 709 (9.78 min), 32-OmonoglycosylhomoYTX at m/z 643 (10.38 $\mathrm{min}$ ), and two unknown homoYTX analogs with $\mathrm{m} / \mathrm{z} 1187$ (7.97 $\mathrm{min}$ ) and with $\mathrm{m} / \mathrm{z} 1171$ (9.18 $\mathrm{min}$ ) (Tables 3 and 4). Also trace amounts of 32-OtriglycosylhomoYTX at $\mathrm{m} / \mathrm{z} 775$ (9.34 $\mathrm{min}$ ) and an unknown analog with $\mathrm{m} / \mathrm{z} 1189$ (7.41 $\mathrm{min})$ were detected. This strain might also contain other homoYTX analogs. The assignment of these analogs is described below.

Ion $\mathrm{m} / \mathrm{z} 1187[\mathrm{M}-\mathrm{H}]^{-}$(7.97 $\left.\mathrm{min}\right)$ : This was the first compound eluted which also showed pseudomolecular ions at m/z $594[\mathrm{M}-2 \mathrm{H}]^{-2}$ and m/z $1209[\mathrm{M}-2 \mathrm{H}+\mathrm{Na}]^{-}$(Fig. 4a). The $\mathrm{MS}^{2}$ fragmentation of the $\mathrm{m} / \mathrm{z} 1187[\mathrm{M}-\mathrm{H}]^{-}$ion generates an ion at $\mathrm{m} / \mathrm{z} 1107$ $\left[\mathrm{M}-\mathrm{SO}_{3} \mathrm{H}\right]^{-}$, which gave daughter ions in the $\mathrm{MS}^{3}$ spectrum at $\mathrm{m} / \mathrm{z}$ 938, 869 and 727 (Fig. 8a). This was the characteristic fragmentation of the polycyclic backbone skeleton of homoYTXs (Ciminiello et al., 2003b) (Fig. 7). The mass and fragmentation of this peak was the same as that of carboxyhomoYTX (Ciminiello et al., 2000), but retention time was different to that of the carboxyYTX standard (4.69 min). Moreover, carboxyhomoYTX appears to be produced by metabolism in shellfish and not in algae (Ciminiello et al., 2000). These facts suggest that this compound is a homoYTX different to carboxyhomoYTX and which has not been previously detected. This analog should be the homologue of the ion at $\mathrm{m} / \mathrm{z} 1173[\mathrm{MH}]^{-}$in the YTX series, found in strains GG1AM, VGO757 and VGO 758.

Ion $\mathrm{m} / \mathrm{z} 1061[\mathrm{M}-\mathrm{H}]^{-}(8.03 \mathrm{~min})$ : This ion displayed a peak with the same mass as that of the noroxohomoYTX (Fig. 4b). In the $\mathrm{MS}^{2}$ analysis a fragment ion with m/z 981 [M$\mathrm{SO}_{3} \mathrm{H}^{-}$was obtained. The $\mathrm{MS}^{3}$ fragmentation of this ion gave a very weak peak at $\mathrm{m} / \mathrm{z}$ 
898 (Fig. 8b) even when applying a high CE. This fragmentation pattern is different to that of the noroxohomoYTX (Ciminiello et al., 2001), but is similar to that of noroxoYTX-enone (m/z $\left.1047[\mathrm{M}-\mathrm{H}]^{-}\right)$shifted in 14 mass units. Therefore the $\mathrm{m} / \mathrm{z} 1061$ $[\mathrm{M}-\mathrm{H}]^{-}$ion should be the 1,3-enone isomer of noroxohomoYTX, the homologue of noroxoYTX-enone (Ciminiello et al., 2001; Miles et al., 2005a) in the YTXs series. The noroxohomoYTX was previously identified in mussels (Ciminiello et al., 2001), but, to our knowledge the noroxohomoYTX-enone, has not been previously mentioned either in dinoflagellate or in shellfish. Therefore it is possible that several ketohomoYTXs exist, as happens with ketoYTXs, but this would need to be confirmed in future studies.

Ion at m/z $1203[\mathrm{M}-\mathrm{H}]^{-}(8.55 \mathrm{~min})$ : was found mainly in cells (Fig. 4c). $\mathrm{MS}^{2}$ of m/z

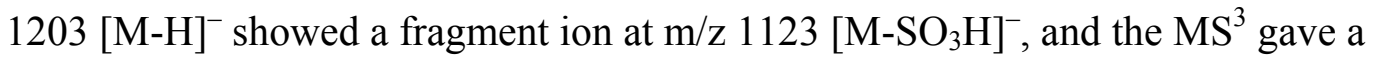
daughter ion at $\mathrm{m} / \mathrm{z} 938$ (Fig. 8c). This is the same LC-MS ${ }^{3}$ spectrum as that of the 44,55-diOH-9-Me-41a-homoYTX, a YTX analog recently identified in a New Zealand strain of P. reticulatum (Finch et al., 2005). Taking into account that this strain produces mainly 1a-homo YTX analogs we think that the m/z $1203[\mathrm{M}-\mathrm{H}]^{-}$ion could be 44,55diOH-9-Me-1a-homoYTX, which should therefore generate the same fragmentation pattern. Further work will be required to determine its assignment.

Ion $\mathrm{m} / \mathrm{z} 1171$ [M-H] $^{-}$(9.18 min): The next peak found was for m/z 1171 (Fig. 4d). Fragmentation by $\mathrm{MS}^{2}$ of the m/z $1171[\mathrm{M}-\mathrm{H}]^{-}$ion showed an m/z $1091\left[{\left.\mathrm{M}-\mathrm{SO}_{3} \mathrm{H}\right]^{-}}^{-}\right.$ daughter fragment, $\mathrm{MS}^{3}$ of this fragment generated the ions at m/z 938, 869 and 727 (Fig. 8d). Fragmentation scheme was consistent with the characteristic fragmentation of the homo- YTXs side chain (Fig. 7). This pattern was coincident with the 45OHhomoYTX, previously detected in shellfish but not in algae (Ciminiello et al., 2002a), however, the retention time differed substantially to the 45-OHYTX standard (8.32 $\mathrm{min})$. These facts indicated that this ion is a homoYTX analog different to 45 OHhomoYTX and had not been previously detected.

Ion $\mathrm{m} / \mathrm{z} 709\left[\mathrm{M}-2 \mathrm{H}^{-2}{ }^{2}\right.$ (9.70 min): As was determined in the glycosyl analogs, the generated peak showed a prominent di-charged ion, where a small signal at m/z 1441 $[\mathrm{M}-2 \mathrm{H}+\mathrm{Na}]^{-}$was detected and the mono-charged ion at m/z $1419[\mathrm{M}-\mathrm{H}]^{-}$was not 
detected at all (Fig. 4e). Fragmentation of the main ion at m/z $709[\mathrm{M}-2 \mathrm{H}]^{2}$ was not possible. $\mathrm{MS}^{2}$ fragmentation of the $\mathrm{m} / \mathrm{z} 1441[\mathrm{M}-2 \mathrm{H}+\mathrm{Na}]^{-}$ion showed as the prominent daughter ion the one at $\mathrm{m} / \mathrm{z} 1305\left[\mathrm{M}-\mathrm{C}_{3} \mathrm{H}_{13} \mathrm{O}+\mathrm{H}\right]^{-}$and also the ion at $\mathrm{m} / \mathrm{z} 1177$ due to the loss of the glycosyl units. MS3 fragmentation of m/z $1305\left[\mathrm{M}-\mathrm{C}_{9} \mathrm{H}_{13} \mathrm{O}+\mathrm{H}\right]^{-}$ion gave the ions at m/z 1235 and 829 (Fig. 8e). This LC-MS ${ }^{3}$ fragmentation matches with that of protoceratin II determined by Konishi et al (2004) in a Japanese strain. Thus indicating the presence of 32- O-triglycosylhomoYTX ( $1 / 4$ protoceratin II) in the VGO764 strain.

Ion $\mathrm{m} / \mathrm{z} 1287[\mathrm{M}-\mathrm{H}]^{-}(10.34 \mathrm{~min})$ : The generated peak showed as prominent ion the $\mathrm{m} / \mathrm{z}$ $643[\mathrm{M}-2 \mathrm{H}]^{-2}$ (Fig. 4f). The same retention time was recorded for G-YTX standard. $\mathrm{MS}^{2}$ fragmentation of the ion m/z $1287[\mathrm{M}-\mathrm{H}]^{-}$gave one daughter ion at m/z 1207 [M$\mathrm{SO}_{3} \mathrm{H}^{-}$and by $\mathrm{MS}^{3}$ ions at m/z 1075 and 1071 (Fig. 8f). LC-MS ${ }^{3}$ fragmentation matches with the G-YTX standard (Souto et al., 2005; Paz et al., 2006) differing in 14 units. Thus indicating the presence of 32-O-monoglycosylhomoYTX which has already been identified and characterised by Konishi et al (2004) in a Japanese strain, together with the di and tri-32-O-glycosylhomoYTX (Konishi et al., 2004). These being the only homoYTX derivates identified up till now in algae.

Ion $\mathrm{m} / \mathrm{z} 1155[\mathrm{M}-\mathrm{H}]^{-}$(11.12 min): This was the prominent ion (Fig. 4g) detected. $\mathrm{MS}^{2}$

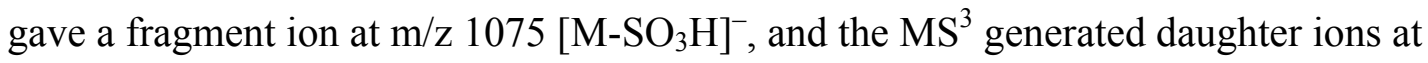
$\mathrm{m} / \mathrm{z}$ 938, 869 and 727 (Fig. 8g). This MS/MS spectrum is characteristic of the 1ahomoYTX side chain. The assignment of 1a-homoYTX was confirmed by comparison with the retention time and fragmentation of the YTX standard (11.15 min) (Fig. 6d). $\mathrm{MS}^{3}$ of homoYTXs is superimposable on the fragmentation of YTXs, but shifted in 14 mass units (Ciminiello et al., 2002b) (Fig. 8).

Other minor compounds detected (data not shown): (i) An unknown analog with m/z $1189[\mathrm{M}-\mathrm{H}]^{-}(7.41 \mathrm{~min})$, which overlapped with the signal of the $\mathrm{m} / \mathrm{z}$ ion 1187 at 7.97 was detected. This compound also displayed pseudomolecular ions at m/z $595\left[\mathrm{M}-2 \mathrm{H}^{-2}\right.$ and $\mathrm{m} / \mathrm{z} 1211[\mathrm{M}-2 \mathrm{H}+\mathrm{Na}]^{-}$(Fig. 4a). The $\mathrm{MS}^{2}$ fragmentation of the m/z $1189[\mathrm{M}-\mathrm{H}]^{-}$ ion generates an ion at $\mathrm{m} / \mathrm{z} 1109\left[\mathrm{MSO}_{3} \mathrm{H}\right]^{-}$, which gave daughter ions in the $\mathrm{MS}^{3}$ 
spectrum at m/z 938, 869 and 727 characteristic of homoYTX analogs. (ii) Also trace amounts of 32-OtriglycosylhomoYTX at m/z $775[\mathrm{M}-2 \mathrm{H}]^{-2}$ (9.34 min) were detected in the extracts.

\subsubsection{General toxin profile of strains}

For VGO757, VGO758 and GG1AM strains (Fig. 4) YTX was the main toxin, but these strains also produced noroxoYTX-enone, 32-O-monoglycosylYTX, 32-OdiglycosylYTX, 44,55-diOH-41ahomoYTX, homoYTX, two unknown YTX analogs (Tables 3 and 4) and possible traces of other YTX analogs. The VGO764 strain (Fig. 5) produced as main toxin the 1a-homoYTX, together with noroxohomoYTX-enone, 32O-triglycosylhomoYTX, 32-O-diglycosylhomoYTX, 32-O-monoglycosylhomoYTX, 44,55-diOH-9-Me-41a-homoYTX and three unknown homoYTX analogs (Tables 3 and 4). It is possible that it could also contain other homoYTX analogs.

It was observed that the analogs found in the three Spanish strains where YTX prevailed, were similar to those found in the strain in which the homoYTX prevailed, but as homoYTX analogs (Tables 3 and 4). Only trace amounts of homoYTX were found in the VGO757, VGO758 and GG1AM strains. But neither YTX nor YTX analogs were found in VGO764 strain. These findings indicate that there were at least two kinds of P. reticulatum, the YTXs producers and the homoYTXs producers.

The calculated contribution percentage of analogs to the total toxin production was very low ranging between $0.1 \%$ and $3.9 \%$ depending on the analog and the strain. The presence of analogs was more important in the culture medium than in cells. Depending on the strain either YTX or homoYTX, was practically the only toxin detected. In the culture medium of the strains VGO757, VGO758 and GG1AM the YTX represented between $92.7 \%$ and $97.6 \%$ of total toxin; and in strain VGO 764 the homoYTX corresponded to a 95.9\% (Table 3). The YTX which remained inside the cells in strains VGO757, VGO758 and GG1AM ranged from $97.2 \%$ to $99.3 \%$ of total toxin; and homoYTX in VGO764 strain was a 99.2\% (Table 4).

The low contribution percentage of YTX analogs was also found in other strains in different studies. In the Norwegian strain AP2 the percentage of trinorYTX, the most 
abundant analog, represented a 3.8\% of total toxin production, and for the other analogs (32-O-mono- and -di-glycosideYTX, ketoYTXs, dihydroxyYTXs, etc.) corresponded to $1-2 \%$ (Samdal et al., 2006). In one Italian strain all the analogs were about $5 \%$ of total YTXs (Ciminiello et al., 2003b).

The YTXs profile determined for the Spanish strains differed from that of other recently studied strains, such as the New Zealand (100 YTXs) (Miles et al., 2006a), Norwegian (5 YTXs) (Samdal et al., 2006), Italian (5 YTXs) (Ciminiello et al., 2003b) and Japan (3 YTXs) (Satake et al., 2006) strains, which mainly produce YTX. To our knowledge, only two other Japanese strains (4 homoYTXs) (Konishi et al., 2004), showed a different profile, and they produced mainly homoYTX, as did the VGO 764 strain studied here. Unlike the VGO 764 strain in the Japanese strain 32-O-mono, -di- and -triarabinosides of 2-homoYTX were also detected, however, YTX analogs were not detected in any of the Mutsu Bay strains (Eiki et al., 2005). In the Yamada Bay (Satake et al., 1999) and in the Norwegian (Samdal et al., 2006) strains 45,46,47-trinorYTX have been found, an analog not detected in any of the Spanish strains studied here. In the New Zealand strain CAWD40, which was studied in depth, a complex YTX profile with 100 analogs was reported, but only the structure of about 20 of them have been identified (Miles et al., 2006a). In a Norwegian strain (AP2) the YTX together with 32O-mono- and -di-glycosideYTX, trinorYTX, three ketoYTXs two dihydroxyYTXs and a hydroxyYTX (not 45-OHYTX) were also found (Samdal et al., 2006). Moreover, in an Italian strain, as in our strains, YTX, homoYTX and noroxoYTX, were detected, but also 45-OHYTX and carboxyYTX (Ciminiello et al., 2003b) were not found in any of the other studied strains. Finally in the Japanese strain, only YTX, trinorYTX and thinorhomoYTX were found (Satake et al, 2006), but neither trinorYTX nor thinorhomoYTX were detected in the Spanish strains studied here. These differences in YTX profile have been found among strains from different locations and evaluated by different analytical methods, therefore differences could be due to the different method of extraction or analysis employed. In the current study the strains were isolated in the same location, grown under the same conditions and analysed by the same method, therefore differences obtained can only be due to strains with a different YTX profile and production.

\subsection{LC-MS analysis vs. LC- FLD analysis}


LC-MS analysis revealed that the strain VGO764 produces mainly homoYTX instead of YTX, whereas LC-FLD analysis showed that all the four Spanish strains produce YTX. As was expected, homoYTX and YTX were indistinguishable by LC-FLD. Therefore the analysis of new strains must first be approached by LC-MS. Then, once the main toxin produced by each strain is identified, it can be determined and quantified by LC-FLD analysis, assuming that homoYTX gives the same molar response as YTX and taking into account that the amount of other analogs is low.

\subsection{Cell biovolume vs. toxin profile}

The significant differences $(\mathrm{p}<0.05)$ found between the strains in cell biovolume (Fig. 1) were consistent with differences found in YTXs profile. Similarly, CCMP1720, CCMP1721 and CCMP404 showed the highest cell biovolume and were not YTX producers, whereas strains GG1AM, VGO757, VGO758 with medium biovolume were YTX producers. Finally, the strain with the smallest biovolume produces homoYTXs. These findings suggest that the studied strains could be different species. In this sense YTX was also found in Gonyaulax spinifera (Rhodes et al., 2006) a dinoflagellate species different from P. reticulatum. Previous studies suggested two different organisms being responsible for production of these homologue series. A genetic study of the strains is necessary to confirm this hypothesis.

In summary, the YTX profile was substantially different between strains. In three out of the four analysed strains YTX was the main toxin and in the fourth homoYTX was the prominent toxin. P. reticulatum is able to produce compounds belonging to both YTX and homoYTX series. Toxin profile of P. reticulatum determined only by LC-MS appeared to be, definitively, more complex than that previously determined. Differences found among strains in YTX amounts, analogs produced and percentage of each analog produced could act as the "molecular fingerprint" (Cembella, 2003), to distinguish and identify strains from different locations.

Small amounts of sample were used to detect by LC-MS the presence of different YTX analogs in the strains studied. Further work, culturing on large scale these dinoflagellates including isolation of these derivatives and NMR spectral analysis will 
be required to fully identify and characterise the structure of the unknown YTX, and above all, the homoYTX analogs detected for the first time in this study

Acknowledgments

We thank Dr. C. O. Miles for his valuable comments on MS analysis. We thank S. Fraga and Isabel Bravo for the morphological identification of the strains. This study was supported by project AGL2005-07924-CO4-01/02 with the collaboration of the project ACU-02-005 INIA and CCVIEO. Beatriz Paz Pino is a pre-doctoral fellow of CSICXunta de Galicia.

References

Aesen, J., Samdal, I.A., Miles, C.O., Dahl, E., Briggs, L.R., Aune, T., 2005. Yessotoxins in Norwegian blue mussels (Mytilus edulis): uptake from Protoceratium reticulatum, metabolism and depuration. Toxicon 45, 265-272.

Alfonso, A., de la Rosa, L.A., Vieytes, M.R., Yasumoto, T., Botana, L.M., 2003. Yessotoxin, a novel phycotoxin, activates phosphodiesterase activity. Effect of yessotoxin on cAMP levels in human lymphocytes. Biochem. Pharmacol. 65, 193208.

Arévalo, F., Pazos, Y., Correa, J., Salgado, C., Moroño, A., Paz, B., Franco, J.M., 2004.

First report of yessotoxins in mussels of Galician Rías during a bloom of Lingulodinium polyedra Stein (Dodge). In: Henshilwood, K., Deegan, B., McMahon, T., Cusack, C., Keaveney, S., Silke, J., O’Cinneide, M., Lyons, D., Hess, P. (Eds.), Fifth International Conference on Molluscan Shellfish Safety. Galway, Ireland, pp. 184-189.

Aune, T., Sorby, R., Yasumoto, T., Ramstad, H., Landsverk, T., 2002. Comparison of oral and intraperitoneal toxicity of yessotoxin towards mice. Toxicon 40, 77-82.

Bianchi, C., Fato, R., Angelin, A., Trombetti, F., Ventrella, V., Borgatti, A.R.,

Fattorusso, E., Ciminiello, P., Bernardi, P., Lenaz, G., Parenti, C.G., 2004.

Yessotoxin, a shellfish biotoxin, is a potent inducer of the permeability transition in isolated mitochondria and intact cells. Biochem. Biophys. Acta 1656, 139-147. 
Boni, L., Ceredi, A., Guerrini, F., Milandri, A., Pistocchi, R., Poletti, R., Pompei, M., 2000. Toxic Protoceratium reticulatum (Peridiniales, dinophyta) in the NorthWestern Adriatic Sea (Italy). In: Hallegraeff, G.M., Blackburn, S.I., Bolch, C.J., Lewis, R.J. (Eds.), Harmful Algal Blooms 2000. Intergovernmental Oceanographic Commission of UNESCO, p. 2001.

CEE, 2002. Commission Decision 2002/225/EC of 15 March 2002. Official J. Eur. Communities L 75, 62-64.

Cembella, A.D., 2003. Chemical ecology of eukaryotic microalgae in marine ecosystems. Phycologia 42, 420-447.

Ciminiello, P., Fattorusso, E., Forino, M., Poletti, R., Viviani, R., 2000. Structure determination of carboxyhomoyessotoxin, a new yessotoxin analogue isolated from adriatic mussels. Chem. Res. Toxicol. 13, 770-774.

Ciminiello, P., Fattorusso, E., Forino, M., Poletti, R., 2001. 42,43,44,45,46,47,55Heptanor-41-oxohomoyessotoxin, a new biotoxin from mussels of the northern Adriatic sea. Chem. Res. Toxicol. 14, 596-599.

Ciminiello, P., Dell-Aversano, C., Fattorusso, E., Forino, M., Magno, S., Poletti, R., 2002a. The detection and identification of 42,43,44,45,46,47,55-heptanor-41oxoyessotoxin, a new marine toxin from adriatic shellfish, by liquid chromatographymass spectrometry. Chem. Res. Toxicol. 15, 979-984.

Ciminiello, P., Dell-Aversano, C., Fattorusso, E., Forino, M., Magno, S., Poletti, R., $2002 b$. Direct detection of yessotoxin and its analogues by liquid chromatography coupled with electrospray ion trap mass spectrometry. J. Chromatogr. A 968, 61-69. Ciminiello, P., Dell-Aversano, C., Fattorusso, E., Forino, M., Magno, S., 2003a. Toxins from Adriatic blue mussels. A decade of studies. Pure Appl. Chem. 75, 325-336.

Ciminiello, P., Dell-Aversano, C., Fattorusso, E., Forino, M., Magno, S., Guerrini, F., Pistocchi, R., Boni, L., 2003b. Complex yessotoxins profile in Protoceratium reticulatum from north-western Adriatic sea revealed by LC-MS analysis. Toxicon $42,7-14$.

Cooney, J.M., Jensen, D.J., Miles, C.O., 2003. Ion-trap LC-MS as a tool for structural characterisation of matrine algal toxins. In: Cawthron Institute, P.R., New Zealand (Ed). HABTech 2003 Workshop, pp. 59-64.

De la Rosa, L.A., Alfonso, A., Vilariño, N., Vieytes, M.R., Yasumoto, T., Botana, L.M., 2001. Maitotoxin-induced calcium entry in human lymphocytes modulation by yessotoxin, Ca2+channel blockers and kinases. Cell. Signall. 12, 711-716. 
Eiki, K., Satake, M., Koike, K., Ogata, T., Mitsuya, T., Oshima, Y., 2005. Confirmation of yessotoxin production by the dinoflagellate Protoceratium reticulatum in Mutsu Bay. Fisheries Science 71, 633-638.

Finch, S.C., Wilkins, A.L., Hawkes, A.D., Jensen, D.J., MacKenzie, L., Beuzenberg, V., Quilliam, M.A., Olseng, C.D., Samdal, I.A., Aesen, J.A.G., Selwood, A.I., Cooney, J.M., Sandvik, M., Miles, C.O., 2005. Isolation and identification of (44-R,S)-44,55dihidroxyyessotoxin from Protoceratium reticulatum, and its occurrence in extracts of shellfish from New Zealand, Norway and Canada. Toxicon 46, 160-170.

Guillard, R.R.L., Hargraves, P.E., 1993. Stichochysis immovilis is an diatom, not a chysophyte. Phycologia 32, 234-236.

Konishi, M., Yang, X., Li, B., Fairchild, C.R., Shimizu, Y., 2004. Highly cytotoxic metabolites from the culture supernatant of the temperate dinoflagellate Protoceratium cf. reticulatum. J. Nat. Prod. 67, 1309-1313.

Mallat, E., Cañete, E., Caillaud, A., Fernandez, M., Bravo, I., Paz, B., Franco, J.M., Diogene, J., 2006. Evidence of yessotoxins in Alfacs Bay-toxic effect evaluation by cellbased assays and toxin profile determination by liquid chromatography. Twelfth International Conference on Harmful Algae, Copenhagen, Denmark. Submitted for publication.

Miles, C.O., Wilkins, A.L., Hawkes, A.D., Selwood, A., Jensen, D.J., Aasen, J., Munday, R., Samdal, I.A., Briggs, L.R., Beuzenberg, V., MacKenzie, A.L., 2004. Isolation of a 1,3- enone isomer of heptanor-41-oxoyessotoxin from Protoceratium reticulatum cultures. Toxicon 44, 325-336.

Miles, C.O., Samdal, I.A., Aesen, J.A.G., Jensen, D.J., Quilliam, M.A., Petersen, D., Briggs, L.R., Wilkins, A.L., Rise, F., Cooney, J.M., MacKenzie, L., 2005 a. Evidence for numerous analogs of yessotoxin in Protoceratium reticulatum. Harmful Algae 4, 1075-1091.

Miles, C.O., Wilkins, A.L., Hawkes, A.D., Selwood, A., Jensen, D.J., Munday, R., Cooney, J.M., Beuzenberg, V., 2005b. Polyhydroxilated amide analogs of yessotoxin from Protoceratium reticulatum. Toxicon 45, 61-71.

Miles, C.O., Wilkins, A.L., H., A.D., Selwood, A.I., Jensen, D.J., Cooney, J.M., Beuzenberg, V., MacKenzie, A.L., 2006a. Identification of 45-hydroxy-46,47dinoryessotoxin, 44-oxo- 45,46,47-trinoryessotoxin, and 9-methyl$42,43,44,45,46,47,55$ - heptanor-38-en-41-oxoyessotoxin, and partial 
characterization of some minor yessotoxins, from Protoceratium reticulatum. Toxicon 47, 229-240.

Miles, C.O., Wilkins, A.L., Selwood, A.I., Hawkes, A.D., Jensen, D.J., Cooney, J.M., Beuzenberg, V., MacKenzie, A.L., 2006b. Isolation of yessotoxin 32-O-[X-1arabinofuranosyl-(50-100)-X-larabinofuranoside] from Protoceratium reticulatum. Toxicon 47, 510-516.

Mitrovic, S.M., Hamilton, B., McKenzie, L., Furey, A., James, K.J., 2005. Persistence of yessotoxin under light and dark conditions. Mar. Environ. Res. 60, 397-401.

Murata, M., Masanori, K., Lee, J.-S., Yasumoto, T., 1987. Isolation and structure of yessotoxin, a novel polyether compound implicated in diarrhetic shellfish poisoning. Tetraedron Lett 28, 5869-5872.

Paz, B., Riobó , P., Fernandez, M.L., Fraga, S., Franco, J.M., 2004. Production and release of yessotoxins by the dinoflagellates Protoceratium reticulatum and Lingulodinium polyedrum in culture. Toxicon 44, 251-258.

Paz, B., Riobó , P., Souto, M.L., Gil, L.V., Norte, M., Fernandez, J.J., Franco, J.M., 2006. Detection and identification of glycoyessotoxin A in a culture of the dinoflagellate Protoceratium reticulatum. Toxicon 48, 611-619

Pé rez-Gómez, A., Novelli, A., A., F.-G., Franco, J.M., Paz, B., Fernandez-Sanchez, M.T., 2006. Potent neurotoxic action of the shellfish biotoxin yessotoxin on cultured cerebellar neurons. Toxicol. Sci. 90, 168-177

Ramstad, H., Hovgaard, P., Yasumoto, T., Larsen, S., Aune, T., 2001. Monthly variations in diarrhetic toxins and yessotoxin in shellfish from coast to the inner part of the Sognefjord, Norway. Toxicon 39, 1035-1043.

Rhodes, L., McNabb, P., de Salas, M., Briggs, L., Beuzenberg, V., Gladstone, M., 2006. Yessotoxin production by Gonyaulax spinifera. Harmful Algae 5, 148-155.

Samdal, I.A., Naustvoll, L.J., Olseng, C.D., Briggs, L.R., Miles, C.O., 2004. Use of ELISA to identify Protoceratium reticulatum as a source of yessotoxin in Norway. Toxicon 44, 75-82.

Samdal, I.A., Aesen, J.A.G., Briggs, L.R., Dahl, E., Miles, C.O., 2005. Comparison of ELISA and LC-MS analyses for yessotoxins in blue mussels (Mytilus edulis). Toxicon 46, 7-15.

Samdal, I.A., Olseng, C.D., Sandvik, M., Miles, C.O., Briggs, L., Torgersen, T., Jensen, D.J., Cooney, J.M., 2006. Profile of yessotoxin analogues in a Norwegian strain of Protoceratium reticulatum. In: Henshilwood, K., Deegan, B., McMahon, T., Cusack, 
C., Keaveney, S., Silke, J., O’Cinneide, M., Lyons, D., Hess, P. (Eds.), Fifth International Conference on Molluscan Shellfish Safety. Galway, Ireland, p. 118.

Satake, M., MacKenzie, L., Yasumoto, T., 1997. Identification of Protoceratium reticulatum as the biogenetic origin of yessotoxin. Nat. Toxins 5, 164-167.

Satake, M., Ichimura, T., Sekiguchi, K., Yoshimatsu, S., Oshima, Y., 1999. Confirmation of yessotoxin and 45,46,47-trinoryessotoxin production by Protoceratium reticulatum collected in Japan. Nat. Toxins 7, 147-150.

Satake, M., Eiki, K., Ichimura, T., Ota, S., Sekiguchi, K., Oshima, Y., 2006. Structure of 45,46,47-trinorhomoyessotoxin, a new yessotoxin analog, from Protoceratium reticulatum which represents the first detection of a homoyessotoxin analog in Japan. Harmful Algae 5, 731-735.

Souto, M.L., Fernandez, J.J., Franco, J.M., Paz, B., Gil, L.V., Norte, M., 2005. Glycoyessotoxin A, a new yessotoxin derivate from cultures of Protoceratium reticulatum. J. Nat. Prod. 68, 420-422.

Stobo, L.A., Lewis, J., Quilliam, M.A., Hardstaff, W.R., Gallacher, S., Webster, L., Smith, E., McKenzie, M., 2003. Detection of yessotoxin in UK and Canadian isolates of phytoplankton and optimization and validation of LC-MS methods. In: Bates, S. (Ed.), Eighth Canadian workshop on Harmful Marine Algae. Gulf Fisheries Centre, Moncton, New Brunswick, Canada, pp. 8-14.

Tubaro, A., Sidari, L., Della-Loggia, R., Yasumoto, T., 1998. Occurrence of yessotoxinlike toxins in phytoplankton and mussels from northern Adriatic Sea. In: Reguera, B.B.J., Fena ndez, M.L., Wyatt, T. (Eds.), Harmful Algae, Xunta de Galicia and Intergovernmental Oceanographic Commission of UNESCO, pp. 470-472.

Tubaro, A., Sosa, S., Carbonatto, M., Altinier, G., Vita, F., Melato, M., Satake, M., Yasumoto, T., 2003. Oral and intraperitoneal acute toxicity studies of yessotoxin and homoyessotoxins in mice. Toxicon 41, 783-792.

Yasumoto, T., Takizawa, A., 1997. Fluorometric measurement of yessotoxins in shellfish by high-pressure liquid chromatography. Biosci. Biotech. Biochem. 61, $1775-1777$. 
Table 1. Location, yield and YTX contents in Protoceratium reticulatum strains by LCFLD analyses

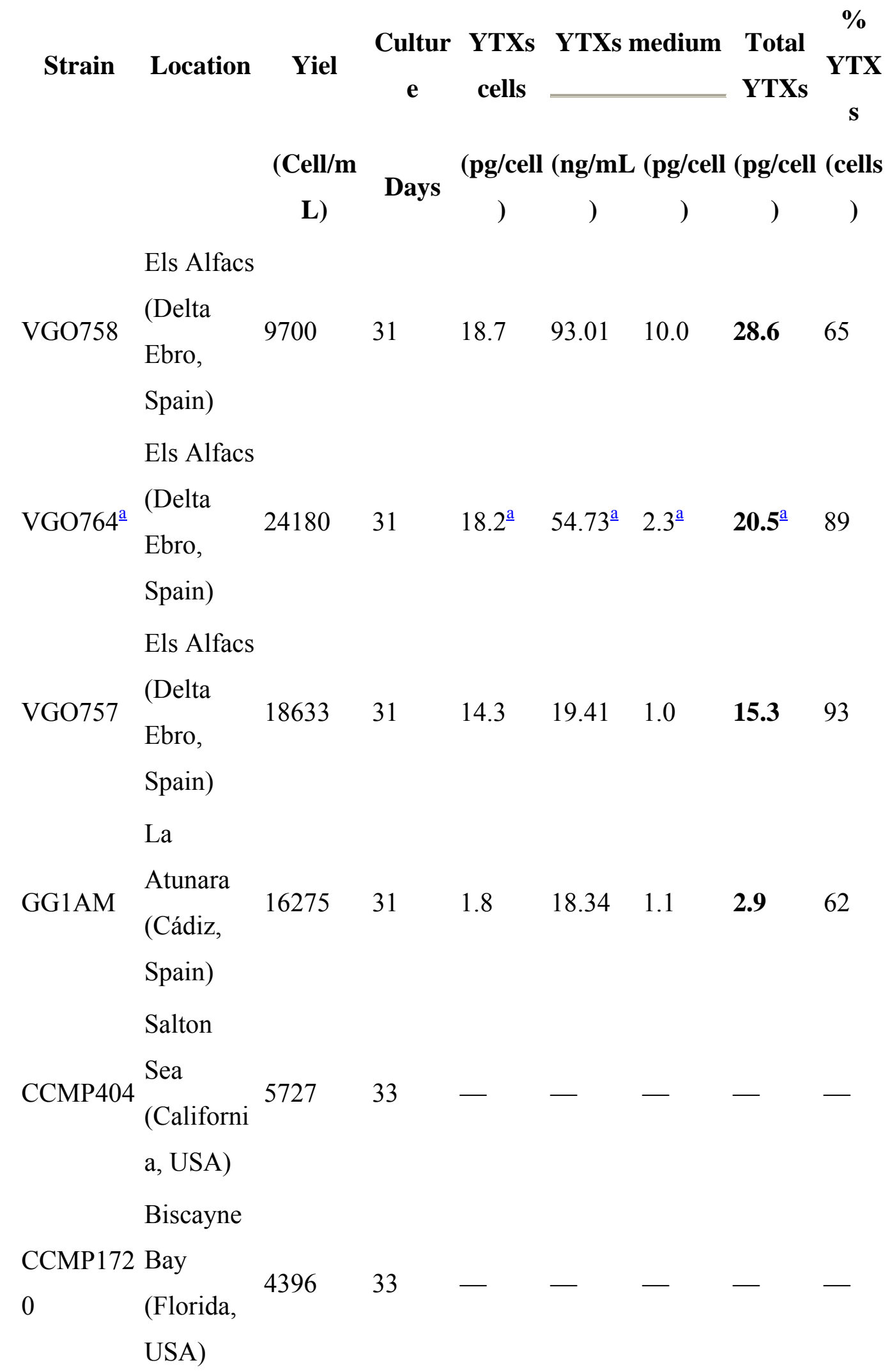




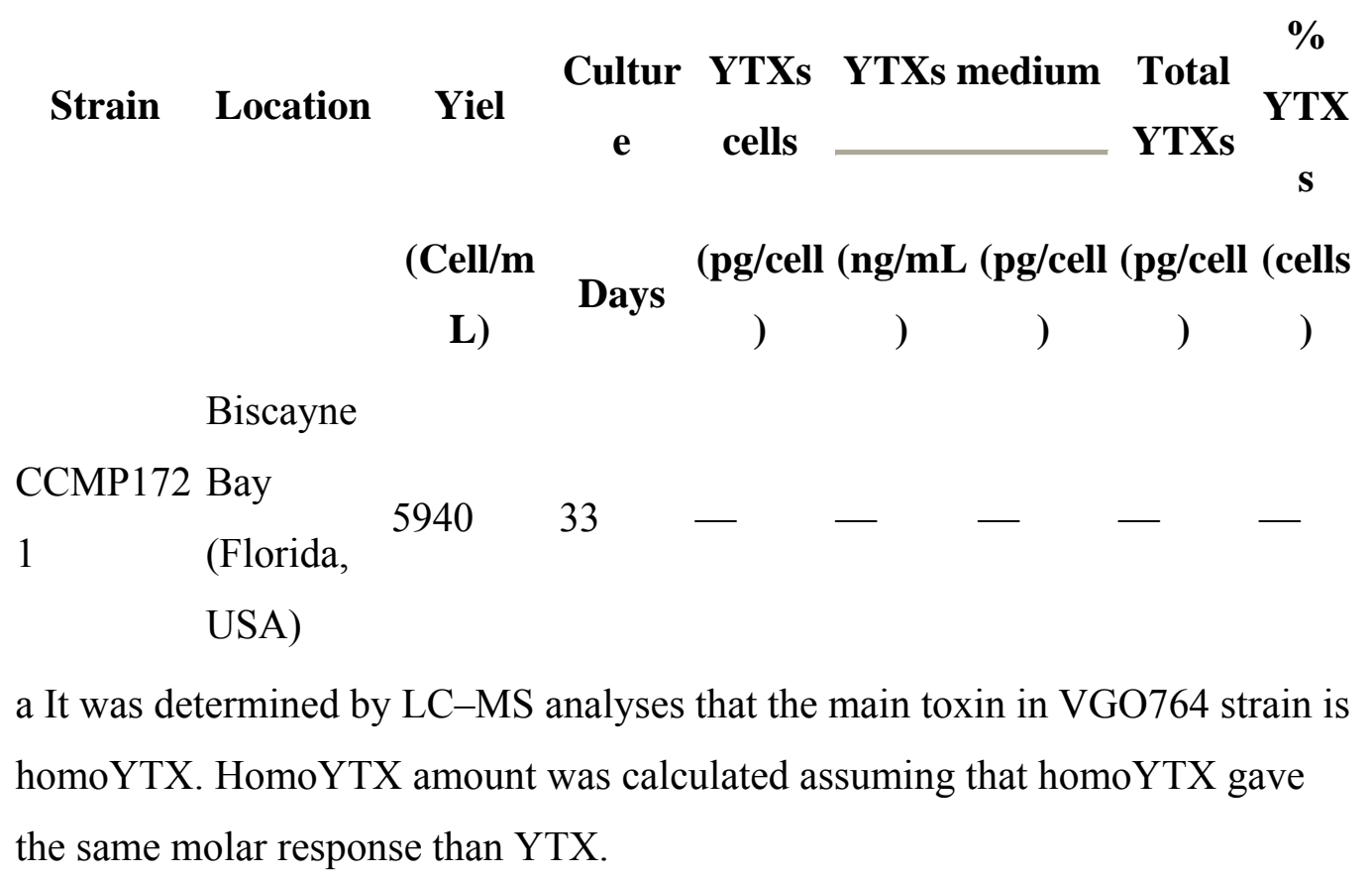

a It was determined by LC-MS analyses that the main toxin in VGO764 strain is homoYTX. HomoYTX amount was calculated assuming that homoYTX gave the same molar response than YTX.

Table 2. Some of the reported YTX concentration in different Protoceratium reticulatum strains

\begin{tabular}{|c|c|c|c|c|}
\hline $\begin{array}{l}\text { P. reticulatum } \\
\text { strain }\end{array}$ & Location & $\begin{array}{l}\text { Analysis } \\
\text { technique }\end{array}$ & $\begin{array}{c}\text { YTXs } \\
\text { (pg/cell) }\end{array}$ & Reference \\
\hline Yamada Bay & Japan & LC-FLD & 14 & $\underline{\text { Satake et al. (1999) }}$ \\
\hline Harina Nada & Japan & LC-FLD & n.d. & $\underline{\text { Satake et al. (1999) }}$ \\
\hline New Zealand & $\begin{array}{l}\text { New } \\
\text { Zealand }\end{array}$ & LC-FLD & 3.0 & $\underline{\text { Satake et al. (1999) }}$ \\
\hline Mutsu Bay & Japan & LC-FLD & 0.9-11 & Eiki et al. (2005) \\
\hline Emilia-Romagna & Italy & LC-FLD & 15.7 & Boni et al. (2000) \\
\hline UW351 & UK & LC-MS & 0.3 & $\underline{\text { Stobo et al. (2003) }}$ \\
\hline UW409 & Canada & LC-MS & 5 & Stobo et al. (2003) \\
\hline Adriatic & Italy & LC-MS & 11.4 & $\begin{array}{l}\text { Ciminiello et al. } \\
\underline{(2003 b)}\end{array}$ \\
\hline CAWD40 & $\begin{array}{l}\text { New } \\
\text { Zealand }\end{array}$ & LC-MS & 10-15 & $\frac{\text { Mitrovic et al. }}{(2005)}$ \\
\hline
\end{tabular}




\begin{tabular}{|c|c|c|c|c|}
\hline $\begin{array}{c}\text { P. reticulatum } \\
\text { strain }\end{array}$ & Location & $\begin{array}{l}\text { Analysis } \\
\text { technique }\end{array}$ & $\begin{array}{l}\text { YTXs } \\
\text { (pg/cell) }\end{array}$ & Reference \\
\hline CAWD40 & $\begin{array}{l}\text { New } \\
\text { Zealand }\end{array}$ & ELISA & 30 & $\begin{array}{l}\text { Samdal et al. } \\
\underline{(2004 a)}\end{array}$ \\
\hline AP2 & Norway & ELISA & $19-22$ & $\begin{array}{l}\text { Samdal et al. } \\
\underline{(2004 \mathrm{a})}\end{array}$ \\
\hline Sognfj03 & Norway & ELISA & $19-34$ & $\begin{array}{l}\text { Samdal et al. } \\
\underline{(2004 a)}\end{array}$ \\
\hline CAWD40 & $\begin{array}{l}\text { New } \\
\text { Zealand }\end{array}$ & ELISA & 8.3 & $\underline{\text { Rhodes et al. (2006) }}$ \\
\hline CAWD127 & $\begin{array}{l}\text { New } \\
\text { Zealand }\end{array}$ & ELISA & n.d. & $\underline{\text { Rhodes et al. (2006) }}$ \\
\hline
\end{tabular}

Table 3. Contribution percentage of each analog detected by $\mathrm{LC}-\mathrm{MS}^{3}$ analyses in culture medium of the Protoceratium reticulatum strains

Rt $\quad m / z \quad$ YTXs Culture medium

Abundance (\%)

Analog GG1AM VG0758 VG0757 VG0764

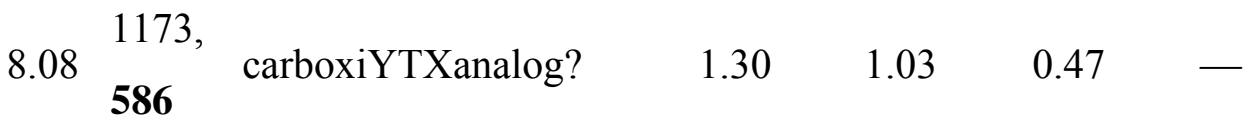

$7.97 \begin{aligned} & 1187, \\ & 594\end{aligned}$ carboxihomoYTXanlog? - $\quad$ - $\quad-\quad 0.75$

$\begin{array}{llllll}8.12 & 1047 & \text { noroxoYTX-enone } & 0.98 & 1.04 & 0.97\end{array}$

8.031061 noroxohomoYTX-enone $\quad-\quad-\quad-\quad-\quad-1.44$

8.61 1189, 44,55-diOH-41a-

594 homoYTX

$\operatorname{tr} \quad-\quad \operatorname{tr}$

$8.68 \begin{array}{lllll}\mathbf{1 2 0 3}, & 44,55-\mathrm{diOH}-9 \mathrm{Me}-41 \mathrm{a}- \\ 601 & \text { homoYTX } & - & - & \end{array}$

9.15 1157, 45-OHYTXanalog? $\quad 1.05 \quad 1.18 \quad 0.58 \quad-$ 
Rt $\quad m / z \quad$ YTXs Culture medium

\section{Analog}

GG1AM VG0758 VG0757 VG0764

578

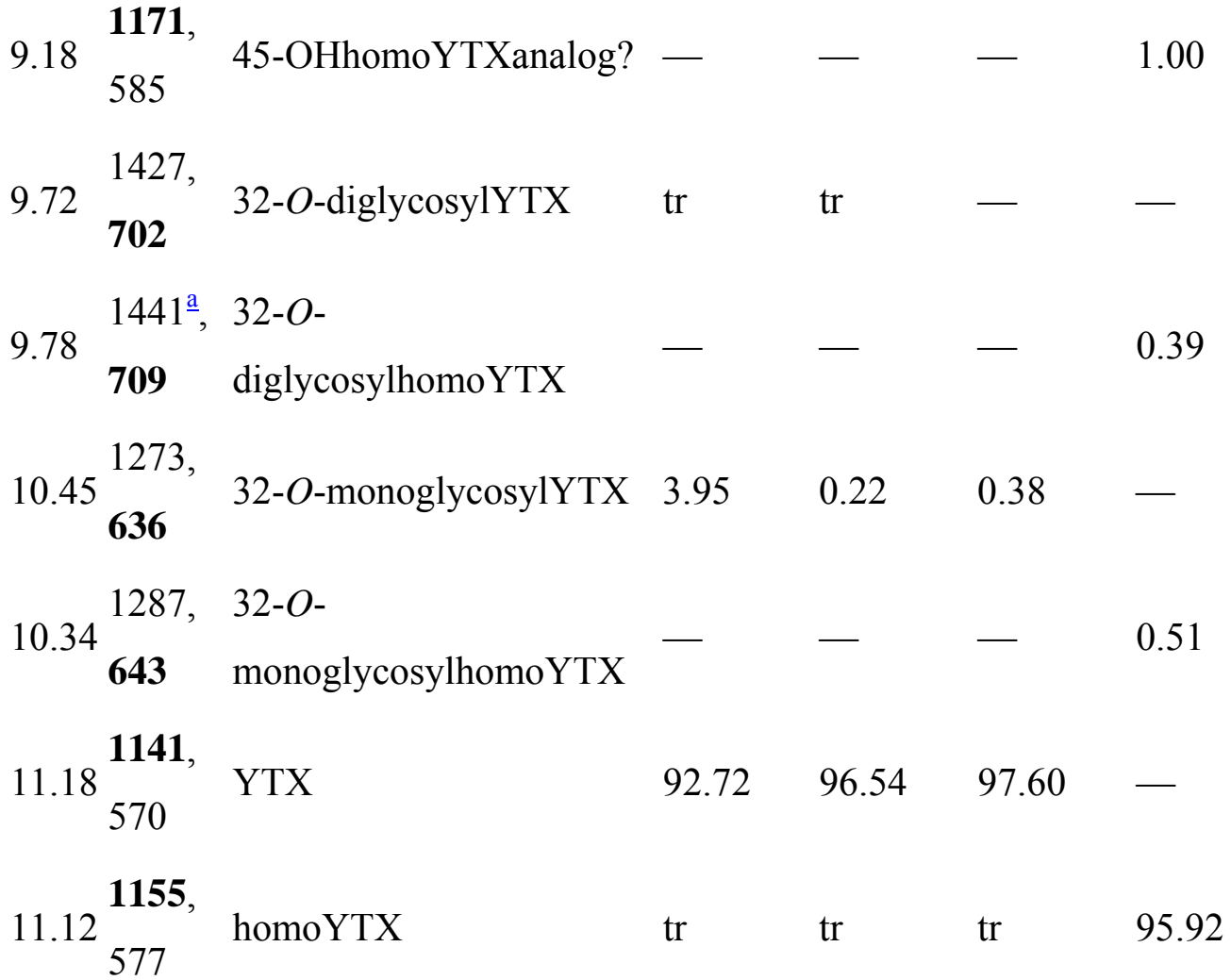

For each analog is given the retention time $(\mathrm{Rt}), \mathrm{m} / \mathrm{z}$ values for $[\mathrm{M}-\mathrm{H}]^{-}$and $[\mathrm{M}-$ $2 \mathrm{H}]^{-2}$ ions, respectively, the name for the analog and the relative abundance observed in the LC-MS analyses. In bold, predominant pseudomolecular ion, $\operatorname{tr}=$ traces.

a For this case the $m / z$ is for the $[\mathrm{M}-2 \mathrm{H}+\mathrm{Na}]^{-}$ion.

Table 4. Contribution percentage of each analog detected by $\mathrm{LC}-\mathrm{MS}^{3}$ analyses in cells in the analysed Protoceratium reticulatum strains
Rt $\quad m / z$
YTXs cells
Abundance (\%)
Analog
GG1AM VG0758 VG0757 VG0764
8.121047 noroxoYTX-enone
0.51
0.13
0.11 
Analog

8.081061 noroxohomoYTX-enone 1189, 44,55-diOH-41a-

8.61 594 homoYTX

8.68 1203, 44,55-diOH-9Me-41a601 homoYTX

9.20 1157, 578 45-OHYTXanalog? 1171

\subsection{6} 585

10.38 32-O-monoglycosylYTX 1.42

$10.361287,32-O-$

643 monoglycosylhomoYTX

11.18

11.18

YTX

11.10 1155, homoYTX 577 $\begin{array}{ll}.42 & 0.42\end{array}$

0.23

GG1AM VG0758 VG0757 VG0764

0.10

0.44

$0.18 \quad 0.31$

0.19

0.09

$97.18 \quad 99.28 \quad 99.34 \quad-$

99.17

For each analog is given the retention time $(\mathrm{Rt}), \mathrm{m} / \mathrm{z}$ values for $[\mathrm{M}-\mathrm{H}]^{-}$and $[\mathrm{M}-$ $2 \mathrm{H}]^{-2}$ ions, respectively, the name for the analog and the relative abundance observed in the LC-MS analyses. In bold, predominant pseudomolecular ion, $\operatorname{tr}=\operatorname{traces}$. 


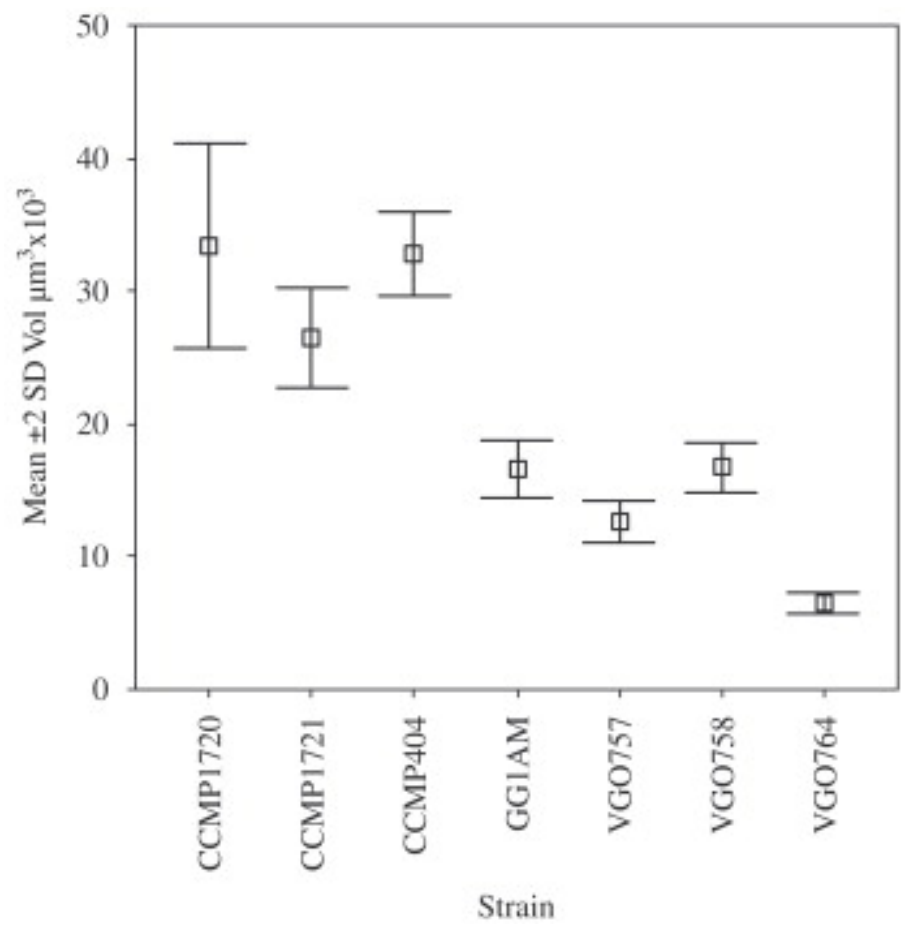

Fig. 1. ANOVA $(<0.05)$ analyses for cell biovolume $\times 10^{3} \mu \mathrm{m}^{3}$ of the Protoceratium reticulatum strains used in this study. 

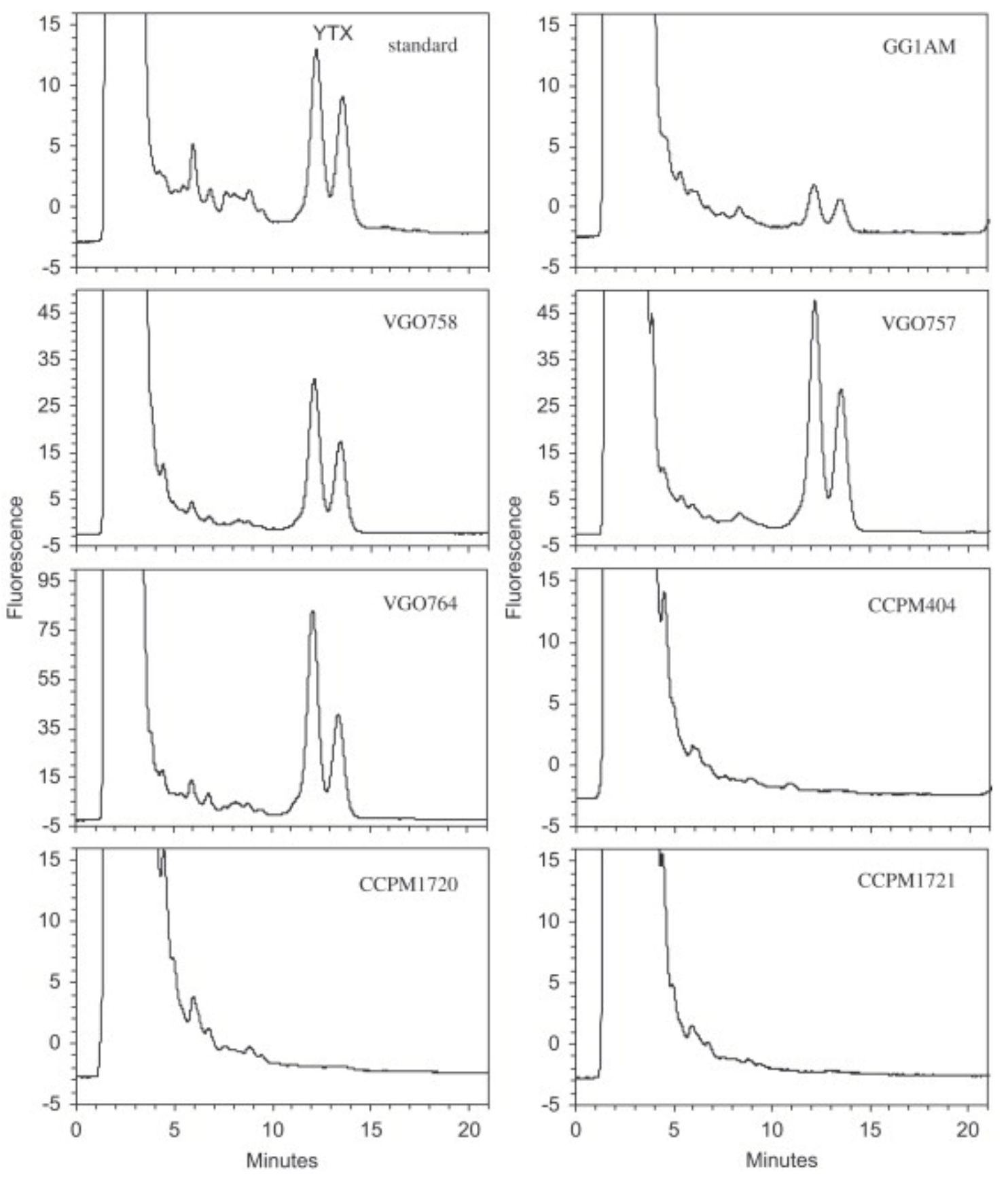

Fig. 2. LC-FLD chromatograms of cells from Protoceratium reticulatum strains: $6 \mathrm{ng}$ of YTX standard, GG1AM, VGO758, VGO757, VGO464, CCPM404, CCMP1720 and CCMP1721. Similar chromatograms were obtained for culture medium. 

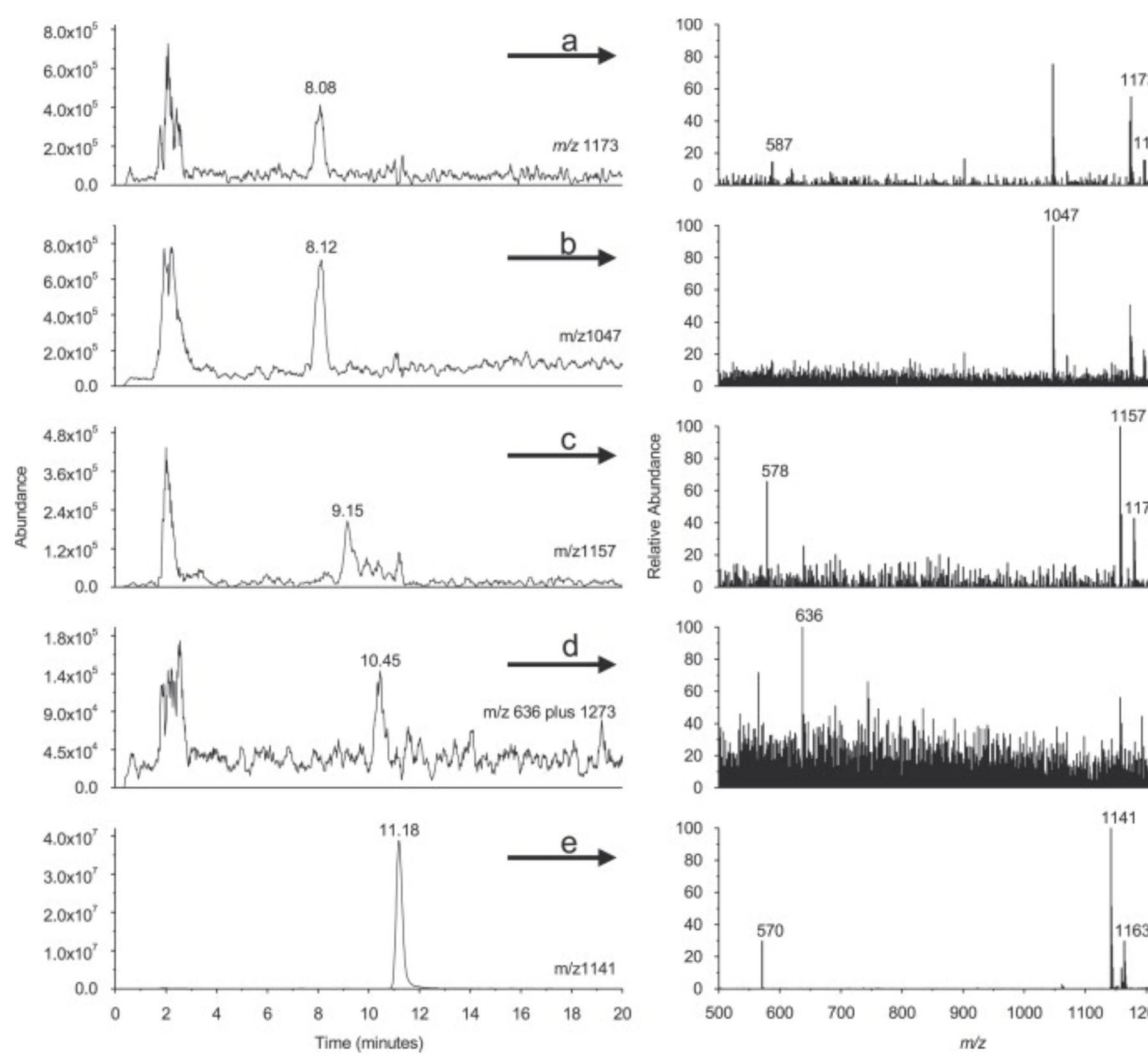

Fig. 3. Selected ion chromatograms and mass spectra obtained from negative LC-MS analyses of culture medium extract from Protoceratium reticulatum VGO758 strain. (a) at $m / z 1173[\mathrm{M}-\mathrm{H}]^{-}$for a YTX analog, (b) at m/z $1047[\mathrm{M}-\mathrm{H}]^{-}$for noroxoYTX-enone, (c) at $\mathrm{m} / \mathrm{z} 1157[\mathrm{M}-\mathrm{H}]^{-}$for a YTX analog, (d) at $\mathrm{m} / \mathrm{z} 636[\mathrm{M}-2 \mathrm{H}]^{-2}$ plus $1273[\mathrm{M}-\mathrm{H}]^{-}$ for 32-O-monoglycosilYTX, (e) at m/z 1141 [M-H] $]^{-}$for YTX. Similar YTX pattern was obtained for GG1AM and VGO757 strains. 

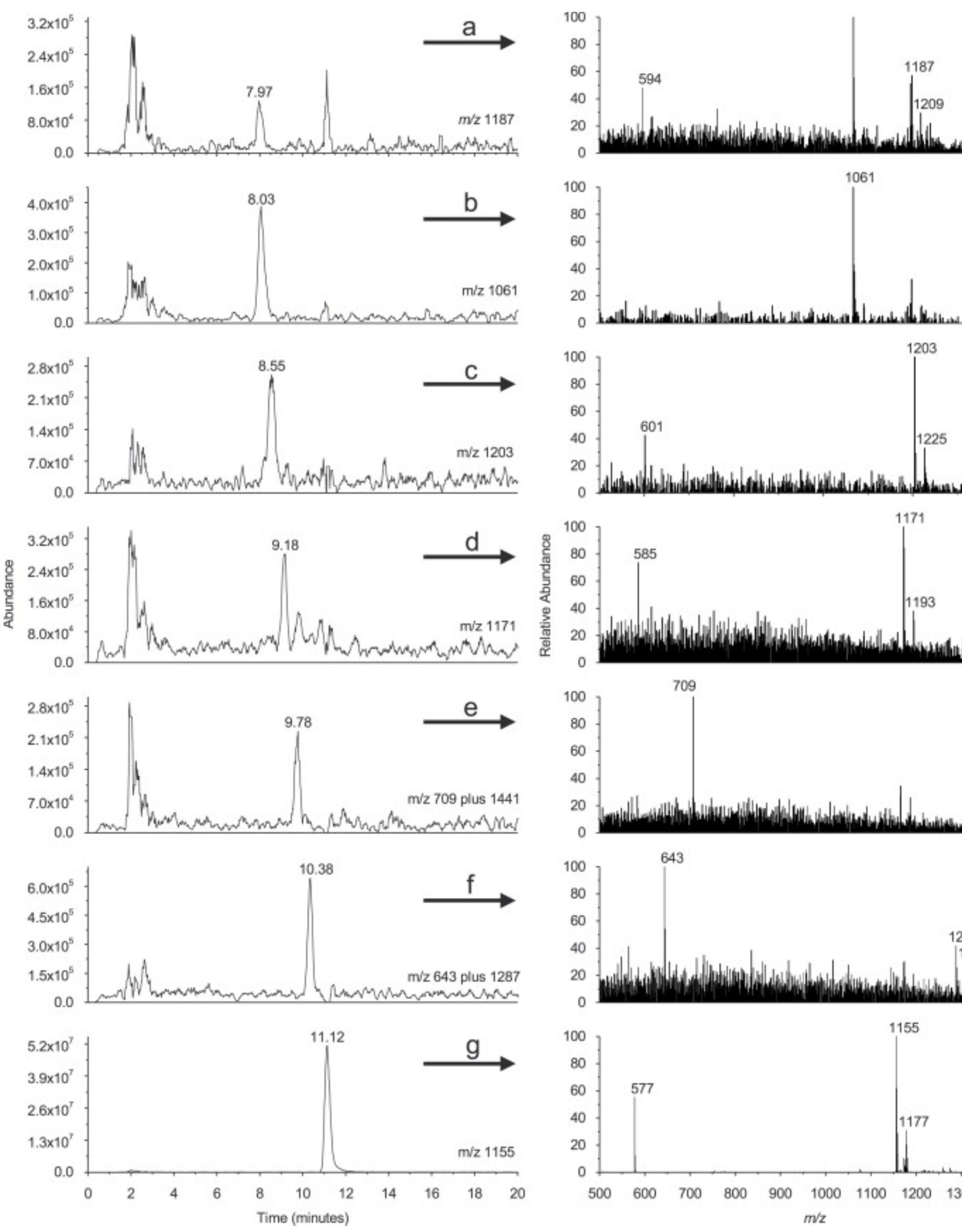

Fig. 4. Selected ion chromatograms and mass spectra obtained from negative LC-MS analyses of culture medium extract from Protoceratium reticulatum VGO764 strain. (a) 
at $1187[\mathrm{M}-\mathrm{H}]^{-}$for a homoYTX analog, (b) at m/z $1061[\mathrm{M}-\mathrm{H}]^{-}$for noroxohomoYTXenone, (c) at $\mathrm{m} / \mathrm{z} 1203$ [M-H] $]^{-}$for 44,55-diOH-9Me-41a-homoYTX? in the cell extract, (d) at $m / z 1171[\mathrm{M}-\mathrm{H}]^{-}$for a homoYTX analog, (e) at m/z $709[\mathrm{M}-2 \mathrm{H}]^{-2}$ plus 1441 [M$2 \mathrm{H}+\mathrm{Na}]^{-}$for 32-O-diglycosilhomoYTX, (f) at $m / z 643[\mathrm{M}-2 \mathrm{H}]^{-2}$ plus $1287[\mathrm{M}-\mathrm{H}]^{-}$for 32-O-monoglycosilhomoYTX and (g) at m/z 1155 [M-H] $]^{-}$for homoYTX.
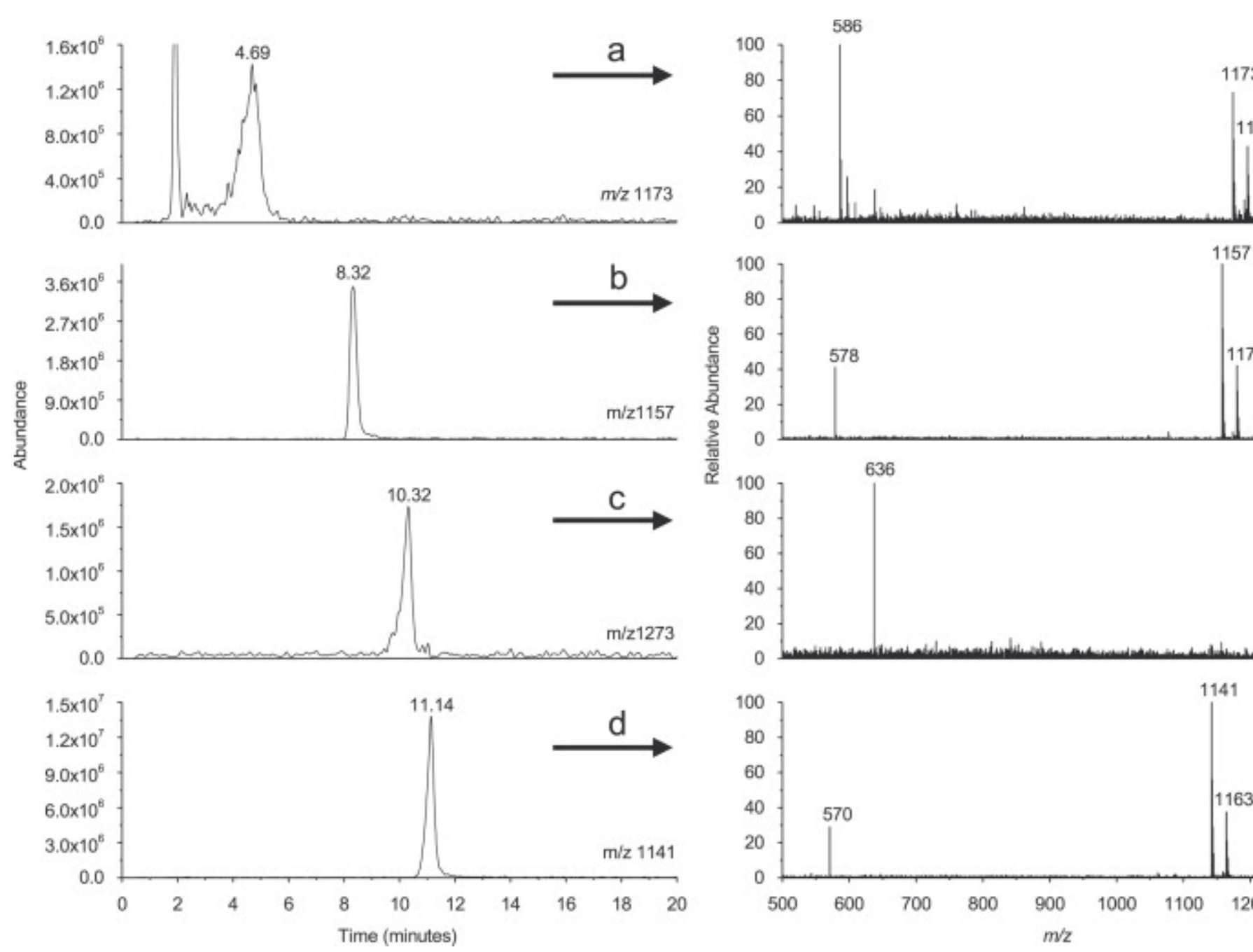

Fig. 5. Selected ion chromatograms and mass spectra obtained from negative LC-MS analyses of YTXs standards. (a) at m/z 1173 [M-M-H] ${ }^{-}$for carYTX, (b) at m/z 1157 [M$\mathrm{H}]^{-}$for 45-OHYTX, (c) at $m / z 636[\mathrm{M}-2 \mathrm{H}]^{-2}$ plus $1273[\mathrm{M}-\mathrm{H}]^{-}$for 32-OmonoglycosilYTX and (d) at m/z $1141[\mathrm{M}-\mathrm{H}]^{-}$for YTX. 


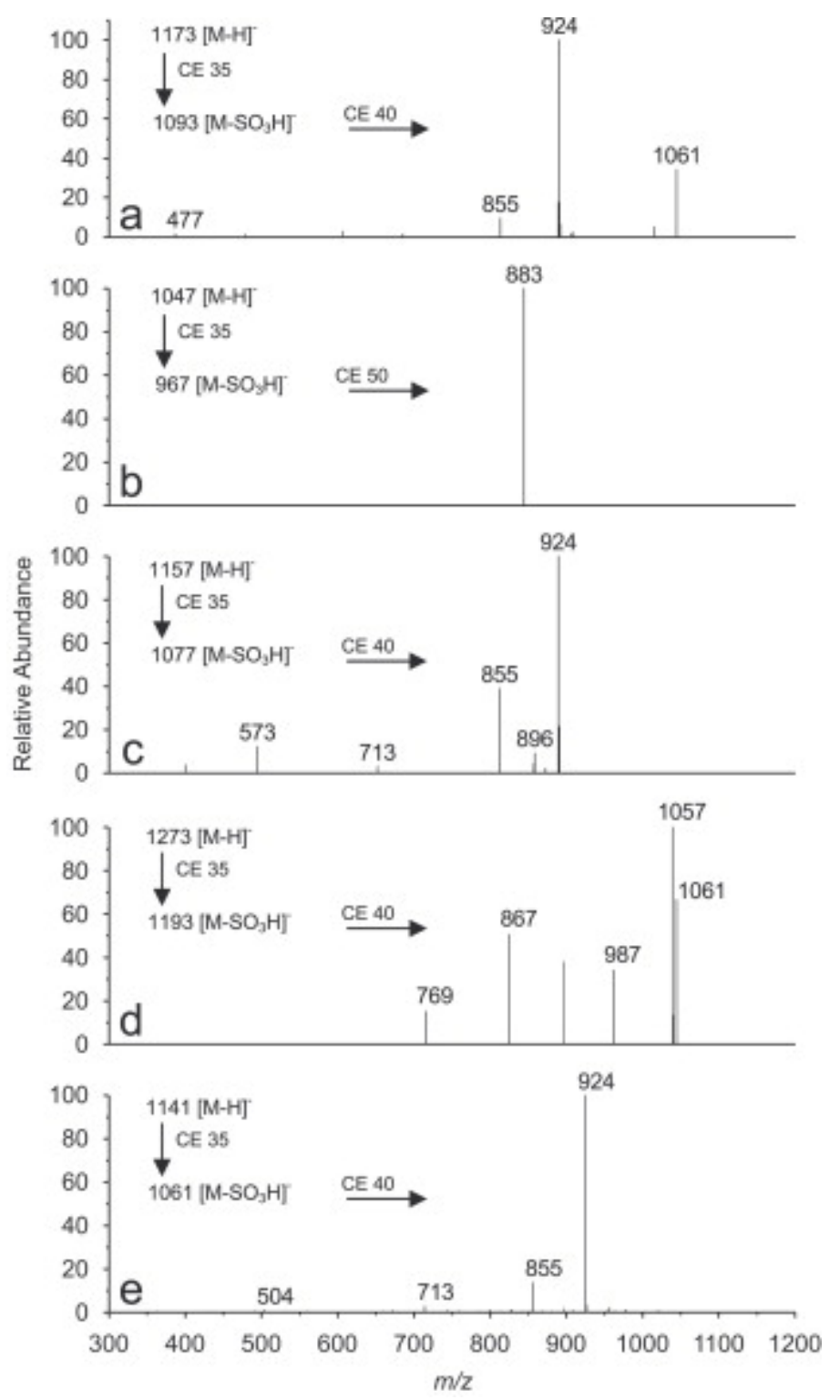

Fig. 6. $\mathrm{MS}^{3}$ spectra for selected peaks observed during $\mathrm{LC}-\mathrm{MS}^{3}$ analyses of culture medium from Protoceratium reticulatum VGO758 strain. Applying a CE of $40 \%$ in the ion: (a) $\mathrm{m} / \mathrm{z} 1093\left[\mathrm{M}-\mathrm{SO}_{3} \mathrm{H}\right]^{-}$, (b) $\mathrm{m} / \mathrm{z} 967\left[\mathrm{M}-\mathrm{SO}_{3} \mathrm{H}\right]^{-}$in this case applying a CE of

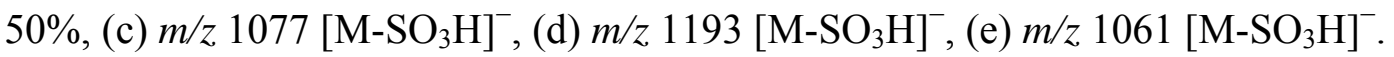
Similar $\mathrm{MS}^{3}$ spectra pattern was obtained for GG1AM and VGO757 strains. 


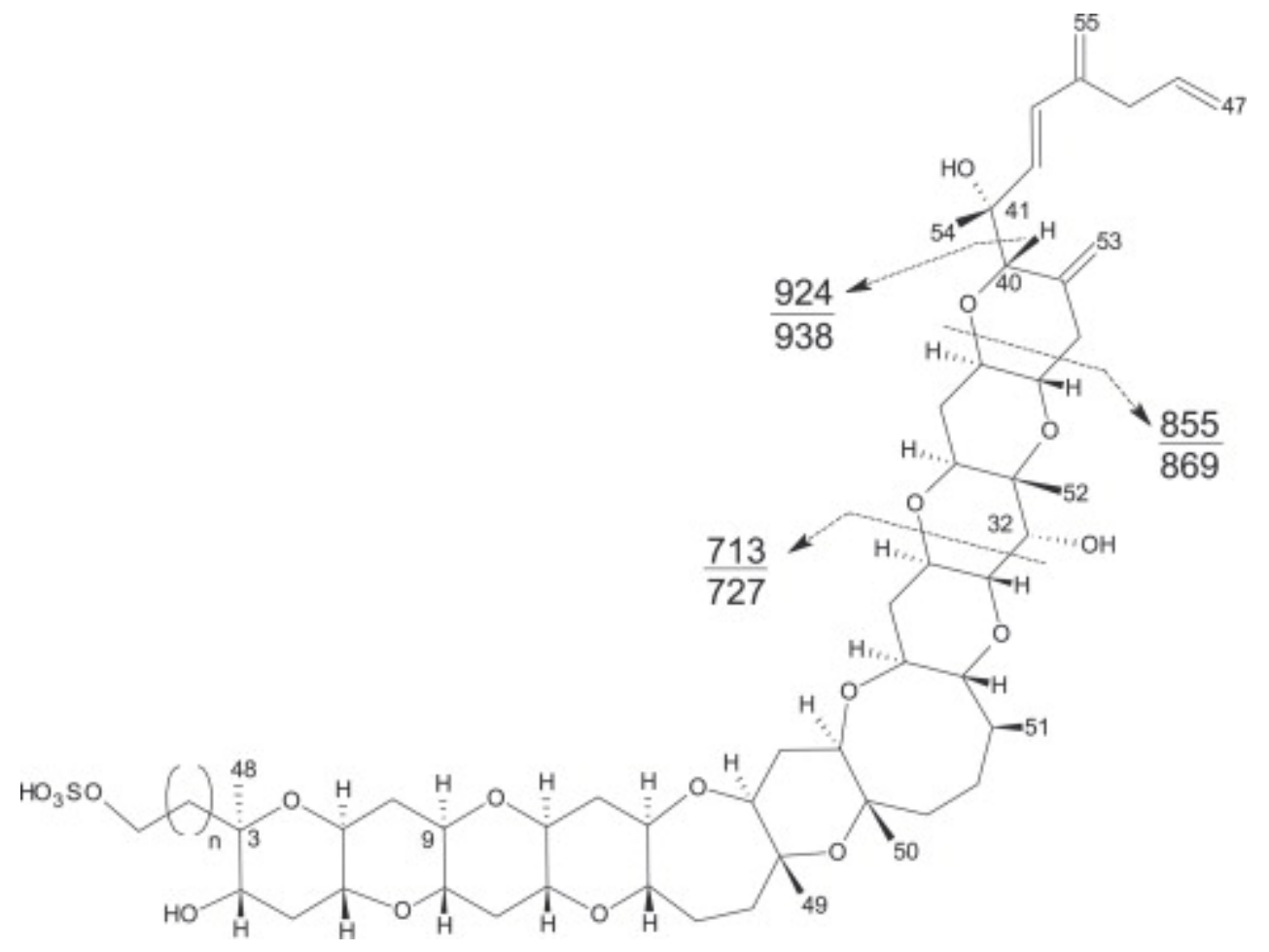

Fig. 7. Structures and characteristic ion product ions observed in the $\mathrm{LC}-\mathrm{MS}^{3}$ analyses of $\left[\mathrm{M}-\mathrm{SO}_{3} \mathrm{H}\right]^{-}$ions of common yessotoxin skeletons $(n=1)$ and above of homoyessotoxin skeletons $(n=2)$. 


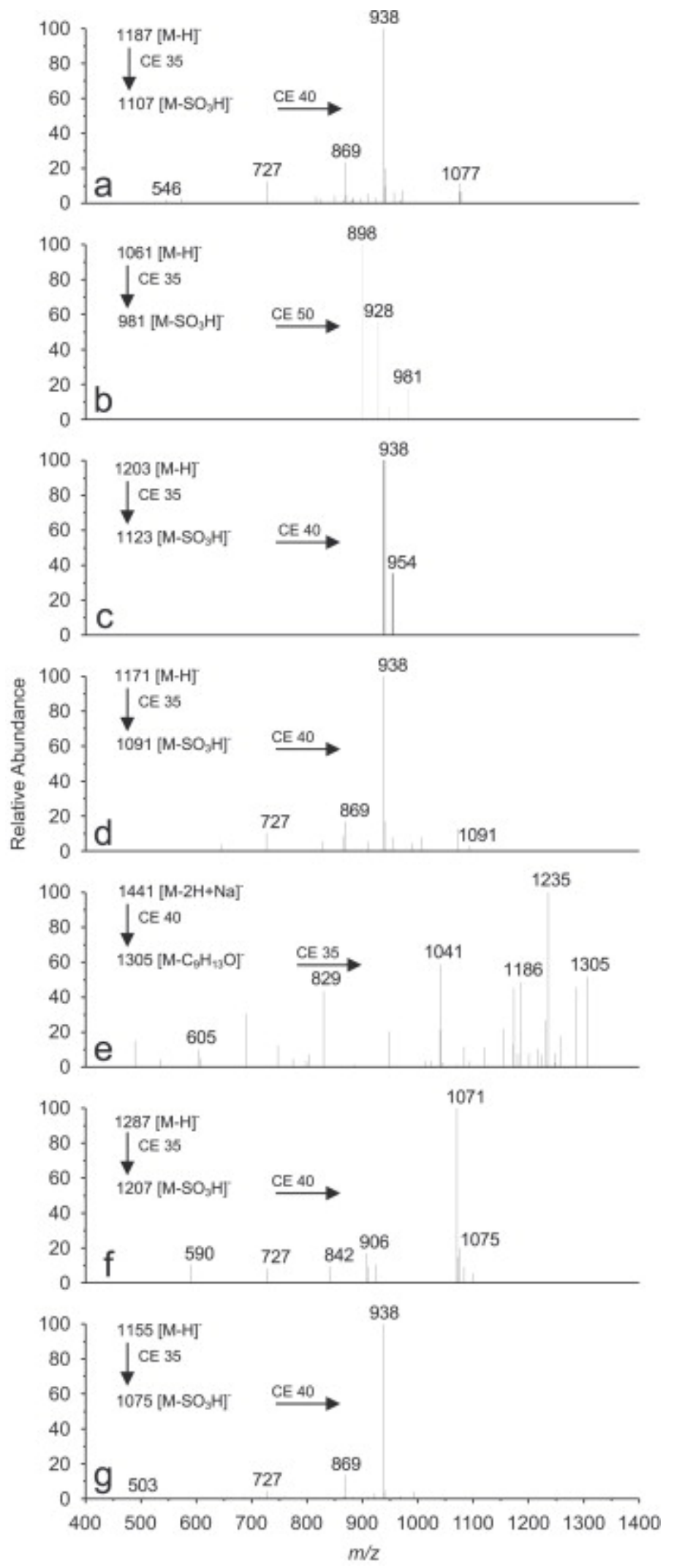

Fig. 8. $\mathrm{MS}^{3}$ spectra for selected peaks observed during LC-MS ${ }^{3}$ analyses of culture medium from Protoceratium reticulatum VGO764 strain. Applying a CE of $40 \%$ in the ion: (a) $\mathrm{m} / \mathrm{z} 1107\left[\mathrm{M}-\mathrm{SO}_{3} \mathrm{H}\right]^{-}$, (b) $\mathrm{m} / \mathrm{z} 981\left[\mathrm{M}-\mathrm{SO}_{3} \mathrm{H}\right]^{-}$in this case applying a CE of 


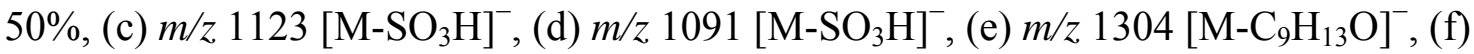
$\mathrm{m} / \mathrm{z} 1207\left[\mathrm{M}-\mathrm{SO}_{3} \mathrm{H}\right],(\mathrm{g}) \mathrm{m} / \mathrm{z} 1075\left[\mathrm{M}-\mathrm{SO}_{3} \mathrm{H}\right]^{-}$. 